\title{
Klasyfikacja wiekowa filmów \\ a wyniki frekwencyjne w ostatniej dekadzie PRL
}

\section{EMIL SOWIŃSKI}

O ile badania dotyczące wyników oglądalności filmów w kinach nie są w polskim filmoznawstwie niczym nowym ${ }^{1}$, o tyle problemem kategorii wiekowych, a tym bardziej ich wpływu na wyniki frekwencyjne, jak dotąd się nie zajmowano. Na wstępie należałoby więc naświetlić, w jaki sposób system ochrony małoletnich widzów funkcjonował w okresie PRL ${ }^{2}$. Instytucją przyznającą filmom kategorie wiekowe była Komisja ds. Kwalifikowania Filmów dla Dzieci i Młodzieży powołana na mocy zarządzenia nr 133 Ministra Kultury i Sztuki z 18 października 1964 r. ${ }^{3}$ Finansowały ją instytucje centralne, które zajmowały się rozpowszechnianiem filmów ${ }^{4}$. Od 1972 r. (aż do 1990 r.) przewodniczącym był Henryk Depta, a w jej skład wchodziło nie więcej niż 35 osób ${ }^{5}$, w tym pedagodzy, psychologowie, socjologowie, krytycy filmowi i filmoznawcy ${ }^{6}$. Kryteria oceny poszczególnych produkcji nie były szczegółowe, gdyż - jak pisał Depta - nie uwzględniałyby różnorodnych sytuacji filmowych ani złożoności procesów rozwojowych dzieci i mło$d z i e \dot{z} y^{7}$. Komisja kierowała się założeniami ogólnymi, a w ocenie zwracano uwagę na fakt, czy treści sq wychowawczo pożądane ${ }^{8}$ a także na stopień ich zrozumienia przez młodocianych oraz wrażliwość uczuciową i możliwości zachwiania jej równowagi ${ }^{9}$. Kategoria wiekowa była ustalana na posiedzeniu tzw. kompletu składającego się z co najmniej trzech członków komisji. Zespół ten - po obejrzeniu filmu, przeprowadzeniu dyskusji, a także zaznajomieniu się z wnioskami Filmowej Rady Repertuarowej ${ }^{10}$ - podejmował uchwałę (większością głosów), która określała, od jakiej granicy wiekowej dany film jest dozwolony ${ }^{11}$. W tym sensie chybiona może być teza, jakoby komisja ,przepisywała” kategorię wiekową z innego kraju. Jak bowiem pisał Henryk Depta: Nie można mechanicznie przyjmować granicy wieku z kraju pochodzenia filmu. Każdy utwór należy dokładnie obejrzeć i zastanowić się przed podjęciem decyzji-wszak powstat w innym kontekście kulturowym: to, co gdzie indziej jest społeczna norma, u nas może budzić sprzeciw ${ }^{12}$. Warto dodać, że w latach 80. - będących przedmiotem zainteresowania autora istniały cztery kategorie wiekowe: „,bez ograniczeń”, „12”, „15”, „18”, podczas gdy do $1974 \mathrm{r}$. było ich pięć ${ }^{13}$.

W niniejszym artykule postaram się odpowiedzieć na pytanie, czy klasyfikacja wiekowa wpływała na wyniki frekwencyjne w kinach w ostatniej dekadzie PRL. Już wstępna analiza repertuarów kinowych połączona $\mathrm{z}$ analizą czasopism poświę- 
conych kulturze filmowej sugeruje, że do najpopularniejszych filmów kinowych w Polsce lat 80 . należały te przeznaczone dla widowni dorosłej. Oto bowiem Wejście smoka (Enter the Dragon, reż. Robert Clouse, 1973) w ciągu sześciu miesięcy wyświetlania (od polskiej premiery w czerwcu 1982 r.) obejrzało ponad pięć milionów widzów, a wśród filmów z największą frekwencją w 1983 r. były: Walka o ogień (Quest for Fire, reż. Jean-Jacques Annaud, 1981), Ucieczka z Nowego Jorku (Escape from New York, reż. John Carpenter, 1981) czy Wielki Szu (reż. Sylwester Chęciński, 1982). Spostrzeżenie to prowokuje również do zadania pytań szczegółowych: Czy pracownicy kin egzekwowali przyznane filmom kategorie? W jaki sposób widzowie dostawali się na filmy dla nich nieprzeznaczone? Jaki był stosunek rodziców małoletnich do przyznanych kategorii?

\section{Problemy metodologiczne i źródła}

Arkadiusz Lewicki pisze: Próbując dziś określić prawdziwa i dokładna liczbę osób, które obejrzały jakąkolwiek produkcję kinematograficzna, stajemy przed zadaniem w zasadzie niemożliwym do wykonania. O ile bowiem będziemy w stanie obliczyć liczbę widzów kinowych, o tyle pozostaniemy bezsilni wobec innych kanałów dystrybucyjnych, z których film dziś korzysta ${ }^{14}$. Nie sposób nie zgodzić się z Lewickim, że przy wielości pól eksploatacyjnych nie jesteśmy w stanie odtworzyć dokładnej liczby widzów. Jednak, w niektórych przypadkach, równie niemożliwym zadaniem jest ustalenie liczby widzów kinowych. Owszem, w odniesieniu do okresu 1990-2019 może się to wydawać dosyć łatwe, zważywszy że możemy korzystać z danych zebranych przez Krzysztofa Kucharskiego ${ }^{15}$ i Annę Wróblewską ${ }^{16}$, a także z bazy Lumiere ${ }^{17}$ lub boxoffice.pl ${ }^{18}$. W wypadku frekwencji na filmach skierowanych do rozpowszechniania w PRL sprawa nie jest już tak oczywista. Podstawowym opracowaniem dla badacza są Mate Roczniki Filmowe (dalej MRF), które zawierały dane statystyczne. Na ich podstawie możemy odtworzyć liczbę widzów kinowych dla lat 1964-1989, przy czym dane dotyczące dwóch ostatnich lat są ograniczone tylko do 20 filmów o największej frekwencji. Na dodatek bardzo często dane z MRF rozmijają się z dokumentami Naczelnego Zarządu Kinematografii (od schyłku PRL - Komitetu Kinematografii), które można odnaleźć w archiwach. Dla przykładu, zamieszczone w MRF dane o widowni 20 filmów o najwyższej frekwencji w 1982 r. są zaokrąglone - w opracowaniu czytamy, że Vabank (reż. Juliusz Machulski, 1981) obejrzało 1441 000, Annę i wampira (reż. Janusz Kidawa, 1981) - 1119 000, a Kłamczuchę (reż. Anna Sokołowska, 1981) - $143000{ }^{19}$. Z kolei dokument zatytułowany Zestawienie informacyjne wyników rozpowszechniania filmów produkcji polskiej z roku 1982 podaje bardziej szczegółowe dane (Vabank - 1441 892, Anna i wampir - 1119 446, Kłamczucha $143759{ }^{20}$. Nie są to oczywiście duże różnice, choć należy zwrócić uwagę, że redakcja wydawanego przez Przedsiębiorstwo Dystrybucji Filmów rocznika nie zaznacza, w jaki sposób zaokrągliła dane. Dopiero ich zestawienie z materiałami Naczelnego Zarządu Kinematografii pokazuje, że w każdym z omawianych filmów mamy do czynienia z zaokrągleniem w dół ${ }^{21}$. Analiza porównawcza obu tabel przynosi jednak więcej nieścisłości. Na przykład, według Rocznika Alicję (reż. Jacek Bromski, Jerzy Gruza, 1980) obejrzało 597000 widzów, a Znachora (reż. Jerzy Hoffman, 1981) - 5579 000. Tymczasem zestawienie archiwalne podaje, że na 
Alicję wybrało się 607379 widzów (czyli o około dziesięciu tysięcy więcej w stosunku do liczby, którą odnajdziemy w MRF), a Znachora 5745627 widzów (a więc o ponad 160 tysięcy więcej). Zważywszy na zgodność pozostałych liczb, można odnieść wrażenie, jakby ktoś wypełniający dokumenty błędnie wpisał dane - choć nie można wykluczyć, że część z nich była świadomie fałszowana. Prawdopodobna jest i taka okoliczność, że jedno z zestawień zostało sporządzone wcześniej, a co za tym idzie, autor raportu mógł nie znać wszystkich danych, które posiadał z kolei drugi sprawozdawca. Są to jednak domniemania, należy bowiem zwrócić uwagę, że nie dysponujemy ani wiedzą pomagającą ustalić przyczynę takich niezgodności, ani innymi danymi - krótko mówiąc informacje z MRF oraz dane z archiwów NZK musimy przyjąć ,z dobrodziejstwem inwentarza”.

W niniejszych rozważaniach posługuję się więc przede wszystkim informacjami z MRF, z tym że dane, które zestawiam, dotyczą frekwencji po roku ich wyświetlania. Wydają się one bardziej reprezentatywne, ponieważ pokazują, jak dana produkcja radziła sobie w kinach przez rok. Pozwala to uniknąć sytuacji, kiedy zestawiamy ze sobą filmy, które weszły do kin w styczniu danego roku z produkcjami mającymi premierę w grudniu. Ponadto dane te były publikowane - w przeciwieństwie do informacji z konkretnego roku - z dokładnością co do jednego widza. W zestawieniach biorę pod uwagę także bardzo ważne dla badań ilościowych informacje na temat liczby kopii, seansów, a także średniej liczby widzów na seans. Niestety - jak już wspominałem - dane te jesteśmy w stanie odtworzyć tylko dla lat 1980-1987.

Informacje o kategoriach wiekowych można odnaleźć w repertuarach kin publikowanych na łamach prasy regionalnej. Niemniej należy pamiętać, że o ile filmy skierowane do szerokiego rozpowszechniania z dużą liczbą kopii były pokazywane w całej Polsce, także w kinach prowincjonalnych (choć oczywiście z opóźnieniem), to do tych ostatnich nie zawsze trafiały produkcje skierowane do wąskiego rozpowszechniania. Należy także zachować pewną ostrożność, zbierając dane z tygodnika „Film”, a dokładniej z jego przedostatniej strony. W umiejscowionym tam dziale $W$ kinach (a w II poł. lat 80. także: W kinach i na kasetach) znajdowały się najważniejsze wiadomości o filmach prezentowanych na ekranach polskich kin. Wśród wielu informacji była również ta, od ilu lat jest dozwolony dany film. Jednakże i w tym dziale nie odnajdziemy wszystkich filmów, które pojawiły się na polskich ekranach, a tylko te wybrane przez redakcję. Dodatkowo analiza magazynu lat 80. pokazuje, że wspomniane informacje często nie zawierały adnotacji o kategorii wiekowej ${ }^{22}$. W związku z tym najlepszym źródłem dla badacza pozostają „Filmowe Serwisy Prasowe” (dalej FSP). Magazyn ten - skierowany głównie do kiniarzy oraz dziennikarzy prasy lokalnej - publikował zestawienia filmów, które miały się pojawić na ekranach kin w danym miesiącu, w tym również wskazania dotyczące kategorii wiekowej. Oczywiście, zdarzały się opisy pozbawione tej informacji, były to jednak wyjątki, a powstałe luki można uzupełnić danymi z repertuarów kin czy tygodnika „Film” (na łamach tego ostatniego można było przeczytać - w ostatnich latach dekady - o tych filmach wprowadzonych na ekrany, które nie doczekały się opisu w FSP). Istotniejszym problemem okazują się jednak rozbieżności. Czasami mogły być pomyłkami redaktorów, innym razem mogły wynikać z rozwoju wypadków. W tym kontekście warto przypomnieć sytuację z końca lat 60., gdy do kina wprowadzono kinową wersję serialu Czterej pancerni i pies 
(reż. Konrad Nałęcki, 1966-1970). Produkcja ta wzbudziła protesty rodziców nieletnich fanów serialu, którzy dziwili się, dlaczego przeznaczono ją dla widzów kinowych od jedenastego roku życia. Jak informowało „Życie Warszawy”, władze wzięty sobie tę dziecięca i rodzicielska krytykę do serca i obniżyly granicę wieku do lat siedmiu ${ }^{23}$. Było to możliwe, ponieważ regulamin prac komisji przewidywał ponowną kwalifikację filmu na wniosek jej przewodniczącego lub dyrektora centralnej instytucji zajmującej się rozpowszechnianiem filmów ${ }^{24}$. Przykład ten pokazuje, że w badaniach nad kategoriami wiekowymi powinno się uwzględniać także kwerendę prasową oraz archiwalną. Natomiast szczególną uwagę należałoby poświęcić listom czytelników do redakcji, a także instytucji zajmujących się rozpowszechnianiem. Do tych pierwszych jesteśmy w stanie dotrzeć podczas kwerend bibliotecznych, natomiast kwerenda archiwalna pokazuje, że listów do instytucji zachowało się niewiele.

\section{Filmy z najwyższą i najniższą frekwencją oraz ich kategorie wiekowe}

Zestawienie filmów z najwyższą frekwencją (zob. Tab. 1) dobitnie pokazuje, że materiały archiwalne często mogą zawierać błędy. Na przykład tabulogram z bazy Centrali Dystrybucji Filmów prezentujący listę filmów o największej liczbie widzów od premiery do 30 maja 1990 r. ${ }^{25}$ nie odnotowuje aż siedmiu filmów, które znajdziemy na liście filmów z największą liczbą widzów opublikowanej w MRF ${ }^{26}$. Pomijając wspomniane nieprawidłowości, należy zwrócić uwagę, że wśród najpopularniejszych obrazów odnajdziemy przede wszystkim produkcje lub koprodukcje amerykańskie (9 filmów, w sumie 65945665 widzów) i filmy polskie (7 filmów, w sumie 59391827 widzów). Pozostałe kraje mają w rankingu jednego lub dwóch reprezentantów i wyniki znacznie skromniejsze. Warta odnotowania jest również rekordowa średnia liczba widzów na seans filmu Człowiek z żelaza (reż. Andrzej Wajda, 1981). Wynika ona z tego, że produkcja ta weszła na duże ekrany w okresie karnawału Solidarności i była dostępna tylko do momentu wprowadzenia stanu wojennego. Jeśli chodzi o kategorie wiekowe, to najwięcej obrazów na tej liście miało przypisaną kategorie „12” (8 filmów), a najmniej „bez ograniczeń wiekowych" (2 filmy). Najwięcej filmów dozwolonych od lat osiemnastu było produkcji/koprodukcji USA (2 filmy). Natomiast żaden będący na liście i pochodzący z tego kraju obraz nie miał kategorii „bez ograniczeń wiekowych”. Produkcje ze Stanów Zjednoczonych zdominowały za to kategorię „12”, albowiem została ona przypisana aż czterem filmom (każdy z nich to przykład tzw. Kina Nowej Przygody). Wśród kategorii „bez ograniczeń wiekowych” znajdziemy dwie produkcje polskie przeznaczone dla najmłodszych (filmy o przygodach pana Kleksa). Z kolei w grupie obrazów przeznaczonych dla dorosłych są: Wejście smoka, dramat wojenny Parszywa dwunastka (The Dirty Dozen, reż. Robert Aldrich, 1967), komedia przygodowa C.K. Dezerterzy (reż. Janusz Majewski, 1985) oraz Walka o ogień. Interesujący jest brak w tym zestawieniu horrorów, albowiem jedyny na wspomnianej liście Duch (Poltergeist, Tobe Hooper, 1982) był przeznaczony dla widzów od piętnastego roku życia (!). 


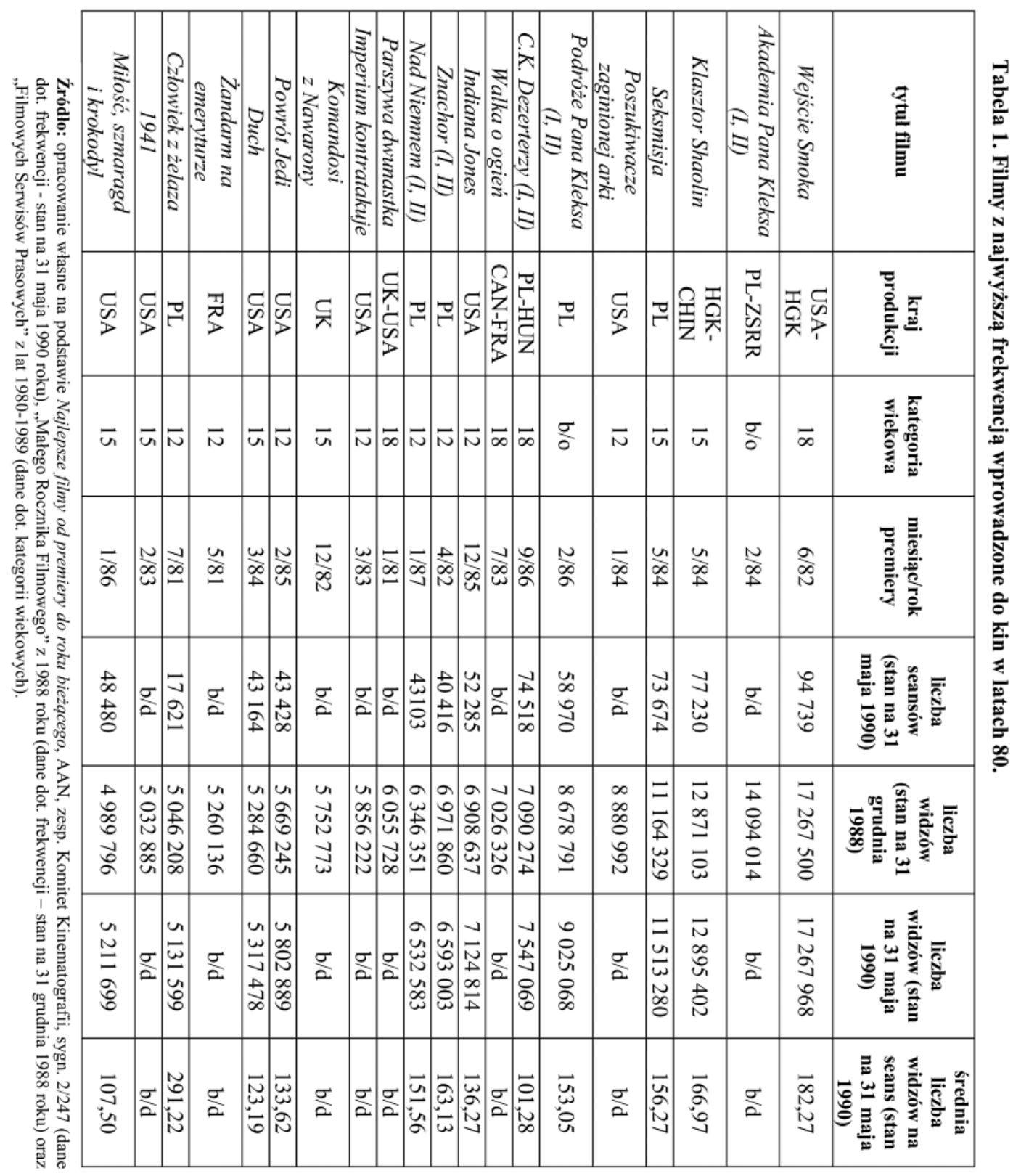


Tabela 2. Filmy premierowe z 1981 r. o najwyższej frekwencji po roku wyświetlania wraz z kategorią wiekowa

\begin{tabular}{|c|c|c|c|c|c|c|c|c|}
\hline tytul filmu & $\begin{array}{c}\text { kategoria } \\
\text { wiekowa }\end{array}$ & $\begin{array}{c}\text { kraj } \\
\text { produkcji }\end{array}$ & $\begin{array}{l}\text { miesiąc } \\
\text { premiery }\end{array}$ & $\begin{array}{c}\text { liczba } \\
\text { kopii } \\
35 \mathrm{~mm}\end{array}$ & $\begin{array}{c}\text { liczba } \\
\text { kopii } \\
16 \mathrm{~mm}\end{array}$ & $\begin{array}{c}\text { liczba } \\
\text { seansów }\end{array}$ & $\begin{array}{l}\text { liczba } \\
\text { widzów }\end{array}$ & $\begin{array}{c}\text { srednia } \\
\text { liczba } \\
\text { widzów } \\
\text { na } \\
\text { seans }\end{array}$ \\
\hline $\begin{array}{l}\text { Czlowiek } \\
\text { z żelaza }\end{array}$ & 12 & PL & $7 / 81$ & 50 & 0 & 16471 & 5038486 & 305,90 \\
\hline $\begin{array}{l}\text { Parszywa } \\
\text { dwunastka }\end{array}$ & 18 & UK-USA & $1 / 81$ & 68 & 50 & 21029 & 3909007 & 185,89 \\
\hline $\begin{array}{c}\text { Żandarm na } \\
\text { emeryturze }\end{array}$ & 12 & FRA & $5 / 81$ & 64 & 0 & 18864 & 3442414 & 182,49 \\
\hline $\begin{array}{c}\text { Ojciec Święty } \\
\text { Jan Pawel II } \\
\text { w Polsce }\end{array}$ & $\mathrm{b} / \mathrm{o}$ & PL & $1 / 81$ & 64 & 0 & 21222 & 3375452 & 159,05 \\
\hline $\begin{array}{c}\text { Żandarm w } \\
\text { Nowym Jorku }\end{array}$ & $\mathrm{b} / \mathrm{o}$ & FRA & $7 / 81$ & 66 & 0 & 16881 & 2462811 & 145,89 \\
\hline Superpotwór & $\mathrm{b} / \mathrm{o}$ & JAP & $3 / 81$ & 60 & 0 & 17436 & 2305249 & 132,21 \\
\hline $\begin{array}{c}\text { Glina czy } \\
\text { lajdak }\end{array}$ & 18 & FRA & $1 / 81$ & 55 & 0 & 15573 & 1879392 & 120,68 \\
\hline $\begin{array}{c}\text { Czas } \\
\text { Apokalipsy }\end{array}$ & 18 & USA & $11 / 81$ & 72 & 0 & 10538 & 1779823 & 168,90 \\
\hline Coma & 18 & USA & $2 / 81$ & 50 & 30 & 13753 & 1763393 & 128,22 \\
\hline Saturn III & 12 & UK & $6 / 81$ & 68 & 0 & 14337 & 1571830 & 109,63 \\
\hline $\begin{array}{c}\text { Wielka } \\
\text { majówka }\end{array}$ & 15 & PL & $11 / 81$ & 27 & 34 & 9763 & 1564469 & 160,24 \\
\hline $\begin{array}{l}\text { Gangsterzy } \\
\text { szos }\end{array}$ & 15 & CAN & $4 / 81$ & 50 & 0 & 13464 & 1419347 & 105,42 \\
\hline Czute miejsca & 18 & PL & $8 / 81$ & 27 & 0 & 7415 & 1112295 & 150,01 \\
\hline Cena strachu & 18 & USA & $3 / 81$ & 41 & 30 & 11662 & 1027009 & 88,06 \\
\hline Miś & 15 & PL & $5 / 81$ & 41 & 0 & 7085 & 662442 & 93,50 \\
\hline $\begin{array}{l}\text { Przygody Ali } \\
\text { Baby i } 40 \\
\text { rozbójników }\end{array}$ & 12 & ZSRR & $6 / 81$ & 35 & 0 & 5465 & 552098 & 101,02 \\
\hline $\begin{array}{c}\text { Bobby } \\
\text { Deerfield }\end{array}$ & 15 & USA & $2 / 81$ & 30 & 0 & 6968 & 448080 & 64,31 \\
\hline Zamach stanu & 15 & PL & $4 / 81$ & 50 & 0 & 4583 & 400473 & 87,38 \\
\hline Pielgrzym & 12 & PL & $7 / 81$ & 40 & 0 & 5611 & 398749 & 71,07 \\
\hline $\begin{array}{c}\text { Przygody } \\
\text { legendarnego } \\
\text { barona } \\
\text { Munchausena }\end{array}$ & $\mathrm{b} / \mathrm{o}$ & FRA & $4 / 81$ & 23 & 14 & 3779 & 375719 & 99,42 \\
\hline
\end{tabular}

Éródło: opracowanie własne na podstawie „Małego Rocznika Filmowego” z 1982 roku oraz „Filmowych Serwisów Prasowych : 1981 roku. 
Gdy przyjrzymy się filmom o najwyższej frekwencji po roku wyświetlania, spostrzeżenia będą podobne. Bez wątpienia w 1981 r. (zob. Tab. 2) kinowym hitem był Człowiek z żelaza - średnia widownia na seans wynosiła prawie 306 osób (jest to wynik rekordowy, zważywszy na fakt, że w tamtym okresie średnia liczba miejsc w kinach wynosiła około $231{ }^{27}$ ). Interesująca jest przyznana filmowi Wajdy kategoria wiekowa - zapis „od lat 12” może świadczyć, że władze kinematografii nie zdecydowały się na wprowadzenie „blokady dostępu” dla nastolatków. Inne filmy z tą samą kategorią to: brytyjski thriller science-fiction Saturn III (reż. Stanley Donen, 1980), radziecko-indyjski (a właściwie bollywoodzki) obraz Przygody Ali Baby i 40 rozbójników (Prikluczenija Ali-Baby i soroka razbojnikow, reż. Łatif Fajzijew, Umesh Mehra, 1980), komediowy Żandarm na emeryturze (Le Gendarme en balade, reż. Jean Girault, 1970) oraz dokumentalny Pielgrzym (reż. Andrzej Trzos-Rastawiecki, 1979). Co ciekawe, drugi dokument opowiadający o pielgrzymce Jana Pawła II był rozpowszechniany bez ograniczeń wiekowych (Ojciec Święty Jan Pawet II w Polsce), podobnie jak inna produkcja o przygodach Ludovica Cruchota, czyli Żandarm w Nowym Jorku (Le Gendarme à New York, reż. Jean Girault, 1965). Dozwolony bez ograniczeń wiekowych był też japoński Superpotwór (Uchu kaijû Gamera, reż. Noriaki Juasa, 1980) oraz animowany obraz produkcji francuskiej Przygody legendarnego Barona Munchausena (Les Fabuleuses aventures du légendaire Baron de Munchausen, reż. Jean Image, 1979). Zaskakująca może być kategoria przyznana brytyjskiemu dreszczowcowi Saturn III z Farrah Fawcett, Harveyem Keitelem i Kirkiem Douglasem w rolach głównych. Dodajmy, że aktorka znana z Aniołków Charliego występuje w jednej ze scen nago, a sam film jest złożony z wielu, jak na tamte czasy, budzących grozę ujęć, raczej nieodpowiednich dla najmłodszych. Wśród najpopularniejszych produkcji odnajdziemy też sześć dozwolonych dla widzów dorosłych, w tym cztery wyprodukowane w USA i po jednej z Polski i Francji.

Dla porównania, gdy przyjrzyjmy się filmom o najniższej frekwencji w $1981 \mathrm{r}$. po roku wyświetlania, nie odnajdziemy tu obrazów przeznaczonych tylko dla dorosłych. Brak również tych pochodzących z krajów kapitalistycznych. Dominują za to produkcje z krajów komunistycznych, a pierwsze miejsce z liczbą 480 widzów (średnio 34 widzów na seans) zajmuje wyprodukowany w Korei Północnej film Bohaterska sanitariuszka (Itchi mothal Chonū, reż. Ch'oe Sunsan, 1977) ${ }^{28}$.

Analiza porównawcza obu tabel pokazuje, że najpopularniejszymi tytułami wśród polskiej widowni były produkcje z krajów kapitalistycznych, a tymi najmniej popularnymi obrazy z krajów komunistycznych ${ }^{29}$. Można oczywiście taki wniosek wysnuć intuicyjnie, nie bacząc na powyższe zestawienie. Jednakże pokazuje to jeszcze jedną ważną zależność. Oto bowiem żaden z obrazów „komunistycznych” nie jest skierowany li tylko dla dorosłych, podczas gdy dla takiej widowni jest przeznaczonych aż pięć filmów „kapitalistycznych”, w tym cztery ze Stanów Zjednoczonych. Podobne ustalenia poczynimy, gdy z wybranego roku zestawimy kategorie wiekowe produkcji ZSRR i Stanów Zjednoczonych. Dla przykładu w 1983 r. wprowadzono do kin 36 filmów wyprodukowanych w Związku Radzieckim, z czego zaledwie siedem przekroczyło granicę 100 tysięcy widzów (19\%). Jeśli chodzi o kategorie wiekowe, to sześć (17\%) z nich weszło do kin bez ograniczeń wiekowych, 21 (58\%) miało kategorię wiekową „12”, 9 (25\%) było przeznaczonych dla widzów od 15. roku życia. Wśród tych 36 obrazów próżno szukać 


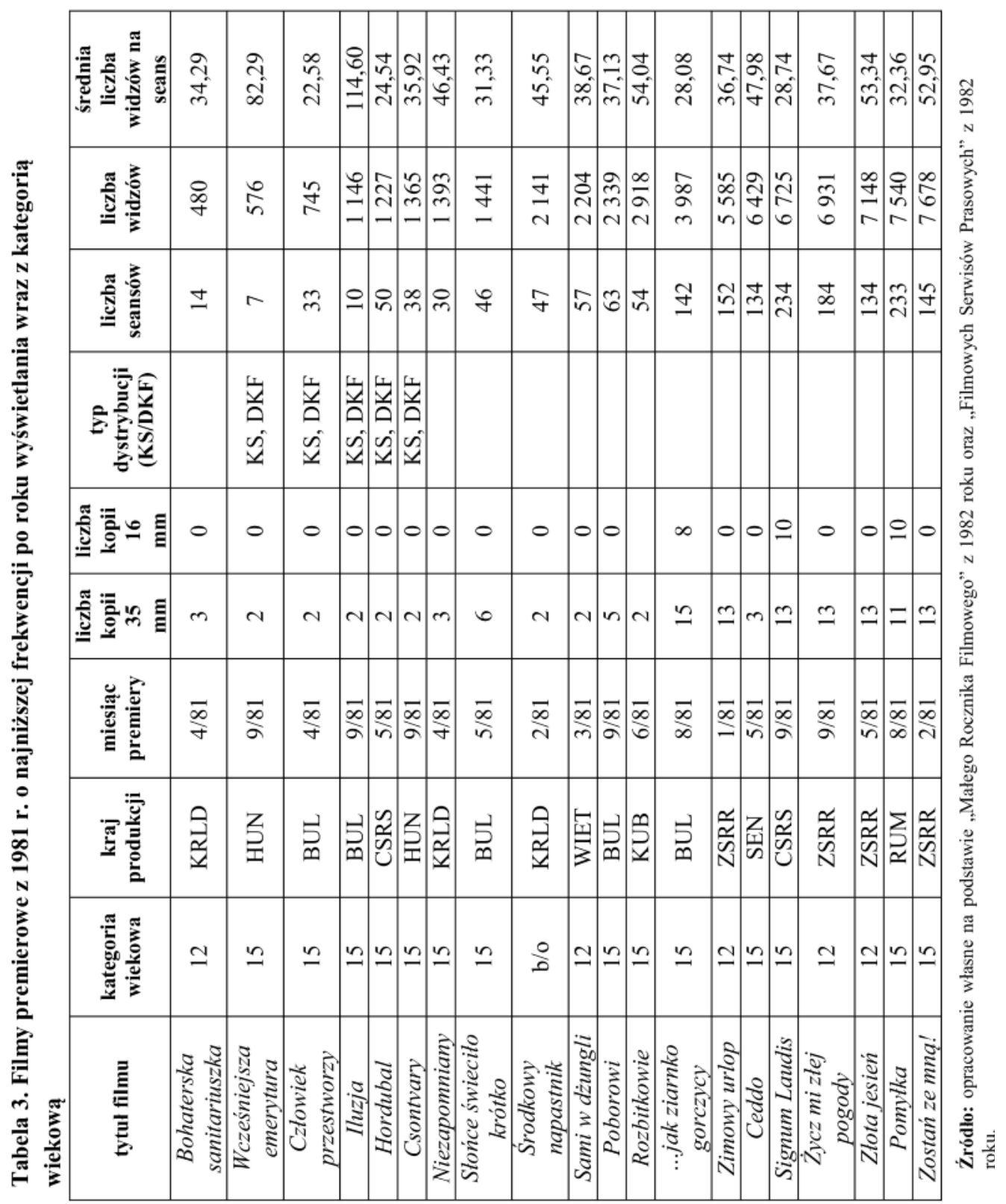


produkcji przeznaczonych tylko dla widowni dorosłej. W tym samym roku w polskich kinach pojawiło się 10 filmów amerykańskich: sześć przeznaczonych dla widzów od piętnastego roku życia, a cztery - tylko dla dorosłych. Każdy przekroczył granicę 100 tysięcy widzów, a sześć z nich milion widzów. Przeznaczony dla widzów od piętnastego roku życia Cały ten zgiełk (All That Jazz, reż. Bob Fosse, 1979), a więc najmniej popularny wśród polskich widzów film amerykański, obejrzało ponad dwa razy więcej osób (436 808), aniżeli najpopularniejszy film produkcji ZSRR (207 766), czyli dozwoloną od lat 12 historyczną Legendę o najwaleczniejszym (Wasilij Busłajew, reż. Giennadij Wasiliew, 1983) ${ }^{30}$.

O ile zestawienia z kolejnych lat o najwyższej frekwencji po roku wyświetlania nie wprowadzją nic nowego, o tyle te ukazujące najmniej popularne produkcje (dodajmy, że pomijane zwykle przez badaczy widowni kinowej) pozwalają wysnuć dodatkowe wnioski na temat związków pomiędzy frekwencją a wyznaczoną kategorią wiekową. Przyglądając się powyższej tabeli z danymi za rok 1985 (zob. tabela 4) zauważymy, że wśród najmniej popularnych obrazów pojawiają się produkcje polskie, a także cztery części szeroko komentowanego dokumentu Shoah (1985) Claude’a Lanzmanna, który mimo dużego zainteresowania wszedł do polskich kin w zaledwie jednej kopii, co świadczy o polityce dystrybucyjnej wobec tego filmu ${ }^{31}$. Znów, poza jednym wyjątkiem - bułgarskim dramatem psychologicznym zatytułowanym Los (Orisiya, reż. Nikoła Korabow, 1983) - żadna z produkcji z krajów komunistycznych - nie uwzględniając polskich - nie była skierowane do dorosłego widza. Wśród polskich filmów dla dorosłych znalazły się Zabicie ciotki (reż. Grzegorz Królikiewicz, 1984) i Dom wariatów (reż. Marek Koterski, 1984). Ciekawy jest przypadek pełnometrażowego debiutu późniejszego twórcy Dnia Świra. Obraz ten - sądząc po średniej liczbie widzów na seans (120 widzów) - był wręcz modny wśród widzów kin studyjnych i Dyskusyjnych Klubów Filmowych, mimo że rozpowszechniano go zaledwie w dwóch kopiach. Niebagatelny wpływ na tę popularność miała polityka władz wobec jego producenta, czyli Studia Filmowego im. Karola Irzykowskiego. Przypomnijmy, że na początku lat 80. wyprodukowano w nim kilka interesujących artystycznie, a zarazem odważnych politycznie współczesnych obrazów wyreżyserowanych przez najmłodszych adeptów sztuki filmowej. Produkcje te często otaczała aura tajemnicy aż do 1984 r., kiedy to sukcesywnie zaczęły pojawiać się na ekranach kin. Można przypuszczać, że najwyższa kategoria wiekowa, oprócz liczby kopii i skierowania do wąskiego rozpowszechniania, mogła być bronią wymierzoną przez władzę w stronę niepokornych debiutantów. Innym przykładem potwierdzającym tę może być sytuacja związana z filmem Nadzór (reż. Wiesław Saniewski, 1983). Debiut ten - mimo dość dobrego przyjęcia na kolaudacji ${ }^{32}$ oraz zapewnień, że powinna go obejrzeć jak największa liczba widzów ${ }^{33}$ - dostał ostatecznie drugą kategorią artystyczną i został skierowany do wąskiego rozpowszechniania ${ }^{34}$, w dodatku z najwyższą kategorią wiekową. Okazał się jednak najpopularniejszym filmem prezentowanym w kinach studyjnych i Dyskusyjnych Klubach Filmowych w 1985 r. (po roku wyświetlania zobaczyło go 132932 widzów, co przy 770 seansach dało zawrotną średnią liczbę widzów na seans wynoszącą 161 osób ${ }^{35}$ ).

Powyższe zestawienia, choć dosyć frapujące, nie dają jednak zadowalającej odpowiedzi na postawione przeze mnie na wstępie pytania. Uwagi o korelacjach pomiędzy kategorią wiekową a frekwencją należy zatem uzupełnić analizą jako- 
Tabela 4. Filmy premierowe z 1985 r. o najniższej frekwencji po roku wyświetlania wraz z kategorią wiekowa

\begin{tabular}{|c|c|c|c|c|c|c|c|c|c|}
\hline tytul filmu & $\begin{array}{c}\text { kategoria } \\
\text { wiekowa }\end{array}$ & $\begin{array}{c}\text { kraj } \\
\text { produkcji }\end{array}$ & $\begin{array}{c}\text { miesiąc } \\
\text { premiery }\end{array}$ & $\begin{array}{c}\text { liczba } \\
\text { kopii } \\
35 \\
\text { mm }\end{array}$ & $\begin{array}{c}\text { liczba } \\
\text { kopii } \\
16 \\
\text { mm }\end{array}$ & $\begin{array}{c}\text { typ } \\
\text { dystrybucji } \\
\text { (KS/DKF) }\end{array}$ & $\begin{array}{c}\text { liczba } \\
\text { seansów }\end{array}$ & $\begin{array}{c}\text { liczba } \\
\text { widzów }\end{array}$ & $\begin{array}{c}\text { średnia } \\
\text { liczba } \\
\text { widzów } \\
\text { na } \\
\text { seans }\end{array}$ \\
\hline $\begin{array}{c}\text { Wieś Vu } \\
\text { Dai }\end{array}$ & 15 & WIET & $9 / 85$ & 3 & 0 & $\mathrm{KS}, \mathrm{DKF}$ & 5 & 159 & 31,80 \\
\hline Los & 18 & BUL & $3 / 85$ & 2 & 0 & KS, DKF & 4 & 533 & 133,25 \\
\hline $\begin{array}{c}\text { Polowanie } \\
\text { na lisy }\end{array}$ & 15 & RUM & $1 / 85$ & 2 & 0 & KS, DKF & 8 & 680 & 85,00 \\
\hline $\begin{array}{c}\text { Bosy } \\
\text { chtopiec }\end{array}$ & 12 & KRLD & $4 / 85$ & 2 & 0 & & 11 & 723 & 65,73 \\
\hline $\begin{array}{c}\text { Mecenas } \\
\text { sztuki }\end{array}$ & 15 & ZSRR & $2 / 85$ & 2 & 0 & KS, DKF & 11 & 860 & 78,18 \\
\hline $\begin{array}{c}\text { Proszę } \\
\text { zapomnieć } \\
\text { o tej } \\
\text { sprawie }\end{array}$ & 15 & BUL & $9 / 85$ & 4 & 0 & & 50 & 1161 & 23,22 \\
\hline $\begin{array}{c}\text { Dzień } \\
\text { dhuższy od } \\
\text { nocy }\end{array}$ & 15 & ZSRR & $11 / 85$ & 2 & 0 & $\mathrm{KS}, \mathrm{DKF}$ & 14 & 1533 & 109,50 \\
\hline $\begin{array}{l}\text { Zagubieni } \\
\text { w piaskach }\end{array}$ & 15 & ZSRR & $11 / 85$ & 2 & 0 & & 31 & 1554 & 50,13 \\
\hline $\begin{array}{c}\text { Niebiański } \\
\text { e zastepy }\end{array}$ & 15 & HUN & $4 / 85$ & 2 & 0 & & 32 & 1673 & 52,28 \\
\hline $\begin{array}{c}\text { Shoah cz. } \\
\text { III }\end{array}$ & 18 & FRA & $12 / 85$ & 1 & 0 & & 30 & 2307 & 76,90 \\
\hline $\begin{array}{c}\text { Shoah cz. } \\
I V\end{array}$ & 18 & FRA & $12 / 85$ & 1 & 0 & & 32 & 2505 & 78,28 \\
\hline $\begin{array}{c}\text { Shoah cz. } \\
\text { II }\end{array}$ & 18 & FRA & $12 / 85$ & 1 & 0 & & 30 & 2536 & 84,53 \\
\hline $\begin{array}{c}\text { Cztery pory } \\
\text { roku }\end{array}$ & 15 & PL & $9 / 85$ & 3 & 0 & $\mathrm{KS}, \mathrm{DKF}$ & 67 & 2883 & 43,03 \\
\hline $\begin{array}{c}\text { Czas } \\
\text { samotności }\end{array}$ & 15 & NRD & $7 / 85$ & 5 & 0 & & 128 & 3669 & 28,66 \\
\hline Shoah cz. I & 18 & FRA & $12 / 85$ & 1 & 0 & & 42 & 4502 & 107,19 \\
\hline $\begin{array}{c}\text { Dom } \\
\text { wariatów }\end{array}$ & 18 & PL & $9 / 85$ & 2 & 0 & $\mathrm{KS}, \mathrm{DKF}$ & 50 & 6018 & 120,36 \\
\hline $\begin{array}{l}\text { Wniosek o } \\
\text { adopcje }\end{array}$ & 15 & NRD & $5 / 85$ & 9 & 8 & & 246 & 7833 & 31,84 \\
\hline $\begin{array}{c}\text { Ratunek } \\
\text { dla miasta }\end{array}$ & 15 & BUL & $9 / 85$ & 12 & 14 & & 335 & 9212 & 27,50 \\
\hline $\begin{array}{c}\text { Emisja } \\
\text { trwa }\end{array}$ & 15 & RUM & $8 / 85$ & 9 & 12 & & 327 & 9627 & 29,44 \\
\hline $\begin{array}{c}\text { Zabicie } \\
\text { ciotki }\end{array}$ & 18 & PL & $9 / 85$ & 4 & 0 & & 168 & 10221 & 60,84 \\
\hline
\end{tabular}

Źródlo: opracowanie własne na podstawie „Małego Rocznika Filmowego” z 1986 roku oraz „Filmowych Serwisów Prasowych” z 1985 roku. 
ściową, a więc wziąć pod uwagę rozmaite parateksty (anonse reklamowe czy plakaty) i konteksty (listy oraz skargi).

\section{(Nie)przestrzeganie kategorii wiekowych}

Konrad J. Zarębski, wspominając z nostalgią seanse kinowe w okresie PRL, pisze: Aby przechytrzyć bileterów, watowało się kurtki, wypinało pierś i mówiło grubym głosem. Znane sa przypadki, kiedy nastoletni młodzieńcy wdzierali się na sale $w$ strojach kobiecych $i$ to na wysokim obcasie... ${ }^{36}$ Gdy rozmawiamy z dorosłymi dziś osobami o ich pierwszych wizytach w kinie, wątek oszukiwania biletera pojawia się bardzo często ${ }^{37}$. Można by nawet - wzorem Marcina Adamczaka, który przed laty zaproponował wyodrębnienie w opowieściach branżowych gatunku o oszukiwaniu władzy i przechytrzeniu cenzora ${ }^{38}$ - wysunąć podobną propozycję w odniesieniu do historii o peerelowskich widzach kinowych, tyle tylko, że dotyczącą oszukania biletera. Wysoka frekwencja na filmach dla dorosłych i wiele zasłyszanych opowieści - jak choćby te prezentowane wyżej - skłaniają do zadania pytania o przestrzeganie nadanych kategorii wiekowych.

Pismo okólne nr 12 Zespołu Rozpowszechniania Filmów Naczelnego Zarządu Kinematografii w sprawie kontroli dzieci i młodzieży uczęszczającej do kin informowało: a) dzieci i młodzież szkolna maja prawo oglądać filmy wytacznie w granicach wieku ustalanych dla każdego filmu; b) na kierownikach kin i obstudze ciąży obowiazek stałej kontroli młodocianych widzów droga sprawdzania dowodów i legitymacji stwierdzajacej wiek ${ }^{39}$. Mając w pamięci te zalecenia, przyjrzyjmy się problematyce skarg złożonych do Okręgowego Przedsiębiorstwa Rozpowszechniania Filmów w Łodzi w 1984 r. Pierwsze miejsce wśród - precyzyjnie wyliczonych przez administracje OPRF-u - typów zażaleń zajmowało Przestrzeganie granicy wieku na wyświetlanych seansach filmów. Jednak nie dotyczyły one obecności młodocianych na filmach dla nich niedozwolonych, były to bowiem głosy rodziców rozżalonych z powodu niewpuszczenia ich podopiecznych ${ }^{40}$. Podobne skargi dochodziły z innych Okręgowych Przedsiębiorstw Rozpowszechniania Filmów. Mieszkaniec Koszalina protestował przeciwko zakazowi wstępu dla jego jedenastoletniego syna na Btękitny grom (Blue Thunder, reż. John Badham, 1983) dozwolony od lat piętnastu ${ }^{41}$. Z kolei mieszkanka Opola, której dziecka nie wpuszczono na film Komandosi z Nawarony dozwolony od piętnastego roku życia, pisała: Ja decyduję o tym, czy dziecko może obejrzeć ten film, bo w końcu to jest film od lat 15-tu a mógłby z powodzeniem być od 12. Nie wiem i ciekawa jestem, kto określa barierę wieku? ${ }^{42}$ Niemal w każdym z dostępnych w Archiwum Akt Nowych sprawozdań OPRF dotyczących skarg i wniosków jest mowa o narzekaniach rodziców na system klasyfikacji wiekowej, zarówno w odniesieniu do 1984 r., jak i kolejnych lat ${ }^{43}$.

Biorąc pod uwagę opowieści o oszukiwaniu bileterów i wspomnianą dokumentację, można postawić tezę, że granice wieku były przestrzegane przez pracowników kina. Tymczasem w sprawozdaniach - ale też w prasie - znajdziemy również skargi dotyczące obecności małoletnich na filmach dla nich niedozwolonych ${ }^{44}$. Są one zwykle związane z niewłaściwym zachowaniem (rozumianym jako głośne) podczas projekcji uniemożliwiającym odbiór pozostałym uczestnikom ${ }^{45}$. W taki oto sposób widz z Sosnowca informował redakcję „Filmu” o zachowaniu małoletnich podczas seansu Niedzielnych igraszek (reż. Robert Gliński, 1983) w kinie 
„Ars” w Dąbrowie Górniczej: Frekwencja (czego należało oczekiwać) mierniutka, co więcej-stabiuteńka, bowiem 2/3 obecnych stanowity dzieci, mimo że na pewno nie do nich ten obraz byt adresowany. Zgoła innego zdania byly panie bileterki, które wręcz ściagaty 12-13 latków niezdecydowanych: iść czy nie iść? Bo to i polski film i chyba o wojnie (tak można byto sądzić po obejrzeniu kilku fotosów). Ale co tam, jeśli pani z kina powiedziała, że to „,piękny film” $i$, to dla was”, nietaktem bytoby odmówić jej mitym namowom (...). Dzieciom najbardziej podobało się, kiedy z ekranu padały niecenzuralne słowa, a że im również nie jest obcy ten zasób leksykalny, dały dowód po projekcji (,, co to, k...a, już koniec?”) ${ }^{46}$. Interesujące w powyższej wypowiedzi jest twierdzenie, jakoby personel kina ściągał dzieci z ulicy na film dla nich nieprzeznaczony. Zważywszy na przytoczony wcześniej fragment pisma okólnego nr 12 i szereg „,niezasadnych skarg rodziców”, opowieść ta wydaje się nieprawdopodobna. Tymczasem, jak w innym liście do redakcji „Filmu” donosił redaktor Leon Bukowiecki, takie działanie personelu nie było niczym nowym: Tak się złożyło, że w czasie wakacji nie widziałem kilku filmów na pokazach prasowych. Musiatem więc chodzić do kina i oto co zauważytem: Film „Zlote dziecko”, w żadnej mierze nie przeznaczony dla dzieci (dozwolony od 12 lat), pokazywano wycieczkom z najniższych klas (a więc 7-10 latkom). W innym kinie, na filmie „Commando” (od 15 lat) petno 10-i 12 latków. W jeszcze innym kinie na „Zabij mnie glino” (chyba sam tytut nie wskazuje na film przeznaczony dla dzieciarni-granicy wieku nie pamiętam), petno dzieci co najwyżej 10-letnich. W każdym z tych kin pytatem kierownika, kierowniczkę, zastępce, czy zastepczynię, a także bileterów i bileterki, na jakiej podstawie wpuszczają te dzieci na filmy dla nich niedozwolone. Wszędzie otrzymałem te same odpowiedzi: „Bez tych dzieci nie bytoby możliwe wykonanie zawyżonych planów finansowych. Wpuszczamy na wszystkie filmy wszystkich jak leci ${ }^{47}$. Należy zauważyć, że oba listy do redakcji pochodzą z 1988 r., z kolei przytaczane przeze mnie skargi z pierwszej połowy lat 80. Niewykluczone, że trudna sytuacja finansowa polskich kin i sfery rozpowszechniania końca lat 80. mogła spowodować, że pod koniec dekady poczynione przed laty ustalenia faktycznie (choć nieoficjalnie) przestały obowiązywać ${ }^{48}$. Trudno się temu dziwić, młodzi mieli co raz szerszy dostęp do legalnych, ale przede wszystkim pirackich filmów na kasetach VHS, a kiniarze dysponowali jedynie ograniczoną liczbą atrakcyjnych premier.

\section{Wcale nie chcę stać się szybko dorosta, ale czasem jestem zmuszona chcieć ${ }^{49}$. Przypadek Wejścia smoka}

W samo potudnie. Upalnie. Na najbardziej ,niechodliwym” seansie-nadkomplet! Tego jeszcze nie widziatem, choć od wielu lat chodzę do kina. Ludzie sa spragnieni atrakcyjnych, a przede wszystkim nowych filmów i jawnie demonstruja swa postawe. Stoja w wielogodzinnych kolejkach - tylko po to, żeby zobaczyć , Wejście smoka”. Wróżki nie potrzeba. Widać, jak na dtoni, że egzotyczny obraz z Hongkongu pobije wszelkie rekordy popularności ${ }^{50}$ - pisał dziennikarz „Odgłosów” kilka tygodni po tym, jak film wszedł na ekrany łódzkich kin. Po roku wyświetlania produkcję obejrzało ponad 11 milionów widzów (średnio 276 osób na seans) ${ }^{51}$, a w sumie ponad 17 milionów ${ }^{52}$. Często kolejki przed kinami bywały dłuższe niż te po produkty deficytowe, a najwięksi fani oglądali film po kilkanaście, a nawet 
kilkadziesiąt razy ${ }^{53}$. Sukces ten może dziwić, zważywszy na fakt, że film trafił do polskich kin dopiero po dziewięciu latach od premiery w Stanach Zjednoczonych ${ }^{54}$ (moment ten zbiegł się także z drastyczną podwyżką cen biletów) ${ }^{55} \mathrm{i}$ był przeznaczony tylko dla widowni dorosłej. Z dzisiejszej perspektywy również kategoria wiekowa mu przyznana może wprawiać w zdumienie. Nie była ona jednak wyjątkiem na tle innych krajów. Dla przykładu w Wielkiej Brytanii produkcja ta otrzymała również najwyższą kategorię, a ówczesny sekretarz British Board of Film Censors uznał, że film eksponuje przemoc wyłącznie w celach rozrywkowych ${ }^{56}$. Można przypuszczać, że podobnie oceniła go polska komisja i - właśnie ze względu na brutalne sceny walk, które mogły być przecież naśladowane przez małoletnich, zdecydowała się na przyznanie najwyższej kategorii wiekowej. Jak bowiem pisał Henryk Depta: Również $i$ ono [okrucieństwo] jest często dramaturgicznie nieuzasadnione. Ale nawet wtedy, gdy jest umotywowane, nie każy okrutny obraz może być udostęniany młodej widowni ${ }^{57}$.

Mimo najwyższej kategorii wiekowej Wejście smoka było obiektem zainteresowania właśnie najmłodszych. Brutalność, która wpłynęła na kategorię wiekową, chyba fascynowała nastoletnich widzów, którzy za wszelką cenę chcieli obejrzeć film, o czym może świadczyć list do redakcji „Filmu” małoletniej mieszkanki Białegostoku: Mam 13,5 i z tego właśnie powodu nie wpuszczono mnie na „Wejście Smoka”. Dlaczego tak wiele ciekawych filmów jest dozwolonych wytacznie dla dorostych i czy „, Wejście smoka” będzie jeszcze wyświetlane, kiedy będę miała 18 lat? Wcale nie chcę stać się szybko dorosła, ale czasem jestem zmuszona chcieć. Psychologowie zapewne uważaja, że ten film jest dla ,niedużej młodzieży” zbyt brutalny, ale my przecież nie jesteśmy tak zastraszająco głupi, ani nie mamy aż tak słodkiego życia, aby ta brutalność miała nas zamroczyć. Tak przynajmniej mi się wydaje ${ }^{58}$. Również w dziale zatytułowanym „Krótko”, publikowanym na drugiej stronie tygodnika „Film”, możemy przeczytać o fenomenie filmu z Brucem Lee wśród nieletnich. O dziesięciolatkach z Kutna, dla których punktem kulminacyjnym kolonii letnich w stolicy był pokaz Wejścia smoka ${ }^{59}$. Pisano także o bileterce kina „Bałtyk” ze Szczecina, która jakoby wpuściła na salę kinową dzieci pięcioletnie ${ }^{60}$. Z kolei, na przeciwległym biegunie, sytuowała się bileterka kina „Romantica" w Kielcach, która ponoć szarpała, popychała i - niczym Bruce Lee - uderzyła w głowę i kopnęła trzynastolatka bez biletu ${ }^{61}$. Na dodatek w szkołach można było odnaleźć fanów wschodnich sztuk walki: „Dziennik Łódzki” pisze o ośmiolatku, który poznat tajemnice Bruce'a Lee i uderzeniem dłoni rozwala paczkę kredek. Robi to podobno cała klasa. O ile wiadomo - Bruce nie miał nic przeciwko kred$\mathrm{kom}^{62}$. Popularne stały się także zajęcia karate, a o uczestnictwie w nich dumnie informowali na łamach prasy nastoletni fani Bruce'a Lee ${ }^{63}$. Aktor grający główną rolę w Wejściu smoka stał się bohaterem ówczesnej popkultury młodzieżowej, a czasopisma prześcigały się w pisaniu artykułów i publikowaniu jego wizerunku ${ }^{64}$ (materiałów tych było tak dużo, że osoby ,zmęczone” ciągłymi publikacjami o gwiazdorze słały nawet krytyczne listy ${ }^{65}$ ). Sukces ten spowodował, że w kinach pojawiły się takie filmy, jak: Klasztor Shaolin (Shàolín Sì, reż. Hsin-yan Chang, 1982), Protector (The Protector, reż. James Glickenhaus, 1985), Karatecy z kanionu żóttej rzeki (Xia jiang yiying, reż. Qimin Lee, 1984), Mistrzyni Wu Dang (Wudang, reż. Sha Sung, 1983), a także Wielka draka w chińskiej dzielnicy (Big Trouble in Little China, reż. John Carpenter, 1986). Co ciekawe, tylko jeden z nich, 
Protector (podobnie jak Wejście smoka, będący koprodukcją USA i Hongkongu), otrzymał najwyższą kategorię wiekową. W sumie wspomniane obrazy zgromadziły w kinach 45225953 widzów i wypromowały nowych idoli sztuki walki - Jeta Lee (Klasztor Shaolin) oraz Jackiego Chana (Protektor).

Z fenomenu popularności sztuk walki skorzystali także polscy twórcy. Piotr Fronczewski powołał do życia fikcyjną postać karateki-piosenkarza Franka Kimono, którego największy hit King Bruce Lee karate mistrz święcił triumfy w notowaniach listy przebojów Programu Trzeciego Polskiego Radia ${ }^{66}$. Z kolei w kinach pojawił się film Karate po polsku (reż. Wojciech Wójcik, 1983), który jeszcze zanim Wejście Smoka zagościło na stałe w polskim repertuarze, był zapowiadany jako dramat psychologiczny Drzazgi ${ }^{67}$. Obraz ten przeznaczono dla widzów od lat 15, a w ciągu roku od premiery obejrzało go 1366163 osób (przy średniej liczbie widzów na seans wynoszącej 123 osoby). Pozwoliło to zająć 11 miejsce na liście filmów z 1983 roku o najwyższej frekwencji po 12 miesiącach wyświetlania (wśród polskich produkcji wyżej były tylko filmy skierowane dla dorosłych: Wilczyca i Wielki Szu) ${ }^{68}$. W porównaniu do liczby widzów kinowych Wejścia smoka wynik ten jest raczej mizerny. Niemniej pozwala przypuszczać, że część widzów ${ }^{69}$ mogła nabrać się na zabieg marketingowy ${ }^{70}$ kojarzący się - jak barwnie ujął to Grzegorz Fortuna - z praktykami duchowych spadkobierców Rogera Cormana funkcjonujacych $w$ warunkach agresywnego kapitalizmu ${ }^{71}$.

\section{Erotyka a kategorie wiekowe. Przypadek kilku filmów erotycznych (?)}

Nina Sławińska recenzję filmu Alabama (reż. Ryszard Rydzewski, 1984) podsumowuje postscriptum: Film dozwolony od lat osiemnastu. A przecież, dobry czy zły, jest to film o młodzieży i dla niej. Reżyserowi zabrano publiczność ${ }^{72}$. Kilka numerów później na łamach tygodnika „Film” pojawia się polemika autorstwa Henryka Depty. Przewodniczący Komisji ds. Kwalifikowania Filmów dla Dzieci i Młodzieży pisze: Film R. Rydzewskiego ukazuje ludzi, dla których jedynymi wartościami sa wartości materialne. Z filmu wynika jasno, że tylko one zdolne sa zapewnić szczęście i sukces życiowy. W tym świecie, w którym żyja bohaterowie filmu, uczciwość jest wyrazem słabości i ,frajerstwa” Być może, zamierzeniem autora filmu byta krytyka tego świata. Ukazany on jednak zostat jako atrakcyjny model skutecznego działania ${ }^{73}$. Przyznana kategoria wiekowa dotyczyła więc ogólnej wymowy filmu, która - według członków komisji - mogła przynieść negatywne konsekwencje wśród młodzieży. Tymczasem kampania reklamowa sugerowała zupełnie coś innego. Pierwszy z plakatów ${ }^{74}$ prezentował kadr z nagą gwiazdą polskiego kina lat. 80 - Marią Probosz, a także informował o specjalnym udziale w produkcji wokalistki Urszuli i zespołu Budka Suflera. Drugi z plakatów eksponował z kolei nagie kobiece piersi, a hasło na plakacie głosiło: love story $w$ filmie Alabama. Ponadto na fotosach kinowych dominowały kadry z leżącą na plaży nagą główną bohaterką. Może to wprawiać w zdumienie, zważywszy na fakt, że obnażona Probosz pojawia się w filmie zaledwie kilka sekund w retrospekcji na początku filmu. Tak skonstruowana kampania promocyjna oraz przyznana kategoria wiekowa mogła się okazać - wbrew zarówno temu, na co utyskiwała Sławińska, jak i temu, czego oczekiwał Depta - wabikiem dla dojrzewającej młodzieży ${ }^{75}$. W rezultacie po roku wyświetlania obraz obejrzało ponad milion 
widzów (18. miejsce na liście filmów o najwyższej frekwencji w 1985 r. po 24 miesiącach wyświetlania) ${ }^{76}$.

Eksponowanie na plakatach nagiego kobiecego ciała, a bardzo często także męskich genitaliów nie było jednak niczym nowym. Jak pisał Karol Jachymek, była to jedna z najczęściej wówczas stosowanych strategii promocyjno-marketingowych, które miały zachęcić widzów do wybrania się na seans ${ }^{77}$. Do przykładów wymienionych przez Jachymka ${ }^{78}$ należałoby także dorzucić strategię zastosowaną przy dystrybucji filmu Czułe miejsca (reż. Piotr Andrejew, 1980). Tę szalenie ciekawą pod względem wizualnym antyutopię (również skierowaną dla dorosłych) obejrzało po roku wyświetlania ponad milion widzów (zob. Tab. nr 2), co może dziś dziwić nawet największych miłośników tego niesłusznie zapomnianego filmu. Jak sądzę, również w tym przypadku liczba ta jest efektem kampanii reklamowej, której celem było wprowadzenie w błąd potencjalnych widzów ${ }^{79}$. Oto bowiem fotosy kinowe skupiały się na atrakcyjnym wyglądzie Hanny Dunowskiej. Z kolei plakaty kinowe prezentowały kształty męskich i żeńskich genitaliów (na plakacie widniało także hasło reklamowe: erotyzm roku 1998) ${ }^{80}$, co wraz z tytułem filmu mogło wywoływać jednoznaczne skojarzenia.

Pytanie, które w tym miejscu należałoby postawić, dotyczy stanowiska, jakie Komisja ds. Kwalifikowania Filmów dla Dzieci i Młodzieży zajmowała w sprawie - często bardzo śmiałych - scen erotycznych. W 1972 roku swój pogląd w tej sprawie przedstawił jej nowo wybrany przewodniczący - Henryk Depta: ...erotyka w filmie jest najmniej dla młodych widzów groźna, niezależnie od posiadania własnych $w$ tym zakresie doświadczeń. Niebezpieczne jest natomiast jej ograniczenie do - jeśli można tak powiedzieć - czystej fizjologii ${ }^{81}$. Ta opinia znalazła zastosowanie także w praktyce. Dowodzi tego sytuacja związana z filmem Matżeństwo Marii Braun (Die Ehe der Maria Braun, reż. Rainer Werner Fassbinder, 1979), którego plakat eksponował nagie piersi. Komisja uznała, że ten film powinien być dozwolony od 15 lat. Wzbudziło to oburzenie jednego z widzów, który zbulwersowany napisał w tej sprawie do Ministra Kultury i Sztuki. Ministerstwo przekazało list przewodniczącemu Komisji, który w taki sposób tę decyzję starał się wyjaśnić jego autorowi: Wedtug Pana „Matżeństwo Marii Braun” to wyłacznie film - używajac Pańskich określeń - „o ustawicznych $i$ wulgarnych scenach damsko-męskich”, co sprawia, że „napawa obrzydzeniem”. Przyzna Pan jednak, że tego rodzaju sceny wcale nie pojawiaja się w filmie , ustawicznie” $i$ że w zwiazku z tym może on także dostarczyć zasadniczo różnych wrażeń. Zawarte w tym utworze sceny erotyczne nie stanowią także wcale sprawy głównej, określając jego problematykę. Ta sprawa, wyraźnie i z niezwykła siła wyrażona w filmie jest zagrożenie wartości humanistycznych przez wysoko rozwinięta cywilizacje przemysłowa oraz system społeczno-polityczny świata kapitalistycznego (...). Film jest tego diagnoza $i$ to diagnoza krytyczna. W tym zawiera się jego zasadnicza - poznawcza i moralnawartość. Uznaliśmy, że odbiorca powyżej 15 lat jest zdolny uchwycić problematykę tego filmu, że zawarte w nim sceny erotyczne ujrzy jako element szerszej i głębszej całości $^{82}$. Pokazuje to, że komisja dość liberalnie traktowała obecne w filmach sceny erotyczne, a o wiele większą wagę przywiązywała do ogólnej wymowy filmu. Takie spojrzenie jest zresztą charakterystyczne dla lat 80. Przypomnijmy, że w wielu ówczesnych czasopismach nagość była stale obecna, jak choćby na ostatniej stronie skierowanego dla młodzieży czasopisma „Razem” czy na łamach 
magazynów filmowych, takich jak „Film” ${ }^{83}$ i „Ekran” ${ }^{84}$, na co także zwracał uwagę Karol Jachymek ${ }^{85}$. Taki stan rzeczy należy również tłumaczyć łagodnym spojrzeniem cenzorów na kwestię erotyki, o czym mogą świadczyć bagatelizowane przez Główny Urząd Kontroli Publikacji i Widowisk listy od widzów zgorszonych obecnością scen erotycznych ${ }^{86}$. Pracownicy urzędu zwykle podsumowywali odpowiedzi w taki sposób: Jednocześnie informuję, że pojęcie pornografii nie zostało dotychczas zdefiniowane w żadnych przepisach prawnych, a ogólnie przyjęte normy obyczajowe ulegają ewolucji. Tak samo wartość artystyczna dzieła nie jest pojęciem jednoznacznym dla wszystkich odbiorców i stąd w poszczególnych przypadkach może rodzić uzasadnione kontrowersje ${ }^{87}$. W zasadzie głos polskich cenzorów ${ }^{88}$ można porównać do opinii o. Bruce'a Rittera - franciszkanina, który (mniej więcej w tym samym okresie) pracował w tzw. komisji Messe'a, powołanej przez prezydenta Reagana w celu zbadania przekazów o charakterze obscenicznym. Ritter zwracał bowiem uwagę, że to, co dla jednego jest nagościa, dla drugiego materiałem erotycznym, dla trzeciego miękka pornografia, dla czwartego twarda, a dla piątego zwykta nuda ${ }^{89}$. Na marginesie warto również zauważyć, że o wiele bardziej rygorystycznie traktowano filmy prezentowane $\mathrm{w}$ telewizji, o czym pisał na łamach „Filmu” Tomasz Beksiński ${ }^{90}$.

Liberalne spojrzenie komisji na erotykę w filmie miało jednak swoje granice. O ile - gromadzące ponad milionową publiczność - produkcje takie, jak Grzeszny żywot Franciszka Buły (reż. Janusz Kidawa, 1980), Seksmisja (reż. Juliusz Machulski, 1983) czy nawet Och Karol (reż. Roman Załuski, 1985) były dozwolone od piętnastu lat ${ }^{91}$, o tyle już Łuk Erosa (reż. Jerzy Domaradzki, 1987), Porno (reż. Marek Koterski, 1990), Powrót wabiszczura (reż. Zbigniew Rebzda, 1989) czy Sztuka kochania (reż. Jacek Bromski, 1989) były skierowane do widowni dorosłej. Warta odnotowania jest również kategoria wiekowa filmu Magiczne ognie (reż. Janusz Kidawa, 1983). Obraz ten przeznaczono dla widzów dorosłych, ale również wśród nich budził kontrowersje. Przywołajmy głos mieszkanki Limanowej, która wraz z pełnoletnimi dziećmi udała się na ten film do kin: Ja niżej podpisana nie zaliczam się do ludzi, którym można by zarzucić pruderię. Jestem bardzo tolerancyjna, $w$ tym również $w$ dziedzinie życia seksualnego (...). To jednak, co ogladnęłam wczoraj na filmie ,, Magiczne ognie” wywołało u mnie naturalny odruch wstrętu i oburzenia, a zarazem wstydu. Byłam bowiem na filmie z moja 19-letnia córka i 22-letnim synem. Córka dostała chyba szoku nerwowego, gdyż $w$ drodze powrotnej z kina (ok. 10 minut drogi) nie odezwała się do mnie ani razu (...). Pokazane w filmie sceny erotyczne, jak i postugiwanie się brukowym słownictwem nie ma nic wspólnego z erotyka, której przecież w filmach nie powinno się unikać, nie mówiąc już o jej potępianiu. Wszak to zbyt wielka i piękna sfera życia ludzkiego, nie zasługująca na wulgaryzowanie ${ }^{92}$. Niewykluczone, że list ten (a być może także głosy innych widzów) spowodował, że decyzją z dnia 18 stycznia 1984 r. Departamentu Programowego NZK wstrzymano rozpowszechnianie filmu i wprowadzono poprawki ${ }^{93}$, a następnie znów wprowadzono go do rozpowszechniania, co również spotkało się z krytycznym odbiorem ${ }^{94}$. Ostatecznie po roku wyświetlania obraz obejrzało niewiele ponad milion widzów ${ }^{95}$.

Komisja o wiele bardziej restrykcyjnie oceniała zawierające śmiałe sceny filmy z krajów kapitalistycznych. Przykładowo, najwyższą kategorię otrzymało Miasto kobiet (La città delle donne, reż. Federico Fellini, 1980), gromadzące po roku wy- 
świetlania 1784531 widzów (średnio 157 osób na seans) ${ }^{96}$. Taką samą kategorię otrzymało wprowadzone do repertuaru u schyłku lat 80. Wielkie żarcie (La Grande bouffe, reż. Marco Ferreri, 1973), jak również repremiera Powiększenia (BlowUp, reż. Michelangelo Antonioni, 1967) ${ }^{97}$. Ze względu na zdumiewającą frekwencję godna uwagi jest także Betty Blue $\left(37^{\circ} 2\right.$ le matin, reż. Jean-Jacques Beineix, 1986). Produkcja ta weszła do polskich kin w grudniu 1987 r. z zastrzeżeniem, że może być rozpowszechniana tylko i wyłącznie na seansach rozpoczynających się po godz. 21.00, w których mogą uczestniczyć widzowie dorośli ${ }^{98}$. W związku z tym obraz ten doczekał się tylko dziesięciu kopii. Mimo tych przeciwności film z Beatrice Dalle ${ }^{99}$ przyciągnął do polskich kin 849804 widzów, co przy niewielkiej liczbie projekcji (2553) przełożyło się na niespotykaną średnią liczbę widzów na seans równą 333 osoby ${ }^{100}$ (przypomnijmy raz jeszcze, że zdawałoby się rekordowy pod tym względem Człowiek z żelaza miał średnią wynoszącą 306 osób, przy czym w owym okresie średnia liczba miejsc w kinach wynosiła około 230) ${ }^{101}$.

$$
* * *
$$

Przywoływane w tekście zestawienia, jak i studia przypadku mogą prowadzić do wniosku, że Komisja ds. Kwalifikowania Filmów Dla Dzieci i Młodzieży o wiele surowiej traktowała produkcje zza żelaznej kurtyny, aniżeli obrazy z krajów komunistycznych. Także w odniesieniu do filmów polskich przyznanie najwyższej kategorii wiekowej mogło być kolejnym - oprócz wąskiego rozpowszechniania i niewielkiej liczby kopii - mechanizmem, który miał spowodować, że dany film zobaczy jak najmniej osób. Wydaje się, że w ten sposób władza starała się zapobiec rozprzestrzenianiu pogłosek o kolejnych ,półkownikach”, albowiem film był dostępny dla publiczności - ale tak naprawdę nielicznej.

Jednak działania te nie spowodowały, że np. filmy amerykańskie miały mniejszą widownię od tych ze Związku Radzieckiego. Przeciwnie, filmy z najwyższą kategorią budziły o wiele większe zainteresowanie potencjalnych widzów, szczególnie wtedy, gdy ich kampania promocyjna była zogniskowana wokół szeroko pojętej erotyki. Nie da się ukryć, że takie obrazy były również (a może i przede wszystkim?) przedmiotem zainteresowania małoletnich, którzy uciekali się do różnych sposobów, aby wprowadzić w błąd bileterów kinowych i znaleźć się na upragnionym seansie. Wszak nie od dziś wiadomo, że to co zakazane, smakuje najbardziej...

EMIL SOWIŃSKI

Artykuł powstał w ramach realizacji projektu „Rozpowszechnianie filmów w Polsce w latach 1945-1989”, finansowanego przez Narodowe Centrum Nauki (2016/22/E/HS2/00135). 


\section{KLASYFIKACJA WIEKOWA FILMÓW...}

${ }^{1}$ Wątek ten niejednokrotnie podejmował w swoich badaniach Arkadiusz Lewicki. Zob. A. Lewicki. Analiza box office'ów jako narzędzie badań filmoznawczych, „Kwartalnik Filmowy” 2014, nr 85; A. Lewicki, Ilu widzów oglądało bergmany? Dystrybucja i widownia filmowa w Polsce wczoraj i dziś - mity i fakty, w: Wokót zagadnień dystrybucji filmowej, red. M. Adamczak, K. Klejsa, Wydawnictwo Biblioteki PWSFTViT, Łódź 2015; A. Lewicki, Kino popularne a polskie społeczeństwo po roku 1989, w: Polskie kino popularne, red. P. Zwierzchowski, D. Mazur, Wydawnictwo Uniwersytetu Kazimierza Wielkiego, Bydgoszcz 2011.

${ }^{2}$ Dziś obowiązuje on tylko w odniesieniu do telewizji. Z kolei ograniczenia wiekowe zamieszczane w repertuarach kinowych mają charakter informacyjny i stanowią rekomendację dystrybutora. Tym samym kina, zgodnie z obowiązującymi przepisami, nie mogą nikomu odmówić sprzedaży biletu na wybrany film.

${ }^{3}$ Zob. Zarzadzenie nr 133 Ministra Kultury i Sztuki z dnia 18 października 1963 roku w sprawie powołania Komisji do Spraw Kwalifikowania Filmów dla Dzieci i Młodzieży, w: Prawo filmowe, red. E. Szelchauz, Wydawnictwo Prawnicze, Warszawa 1980, s. 96-97. Od I poł. lat 50. analogiczna komisja działała w ramach Ministerstwa Oświaty.

${ }^{4}$ W latach 80 . były to kolejno: Zjednoczenie Rozpowszechniania Filmów (1976-1982), Przedsiębiorstwo Dystrybucji Filmów (19821987) i Centrala Dystrybucji Filmów (19881990).

${ }^{5}$ Zarzadzenie $n r 133$... dz. cyt., s. 96.

${ }^{6}$ K. J. Zarębski, Wszystko wolno? „Kino” 1999 , nr 3, s. 11.

${ }^{7}$ H. Depta, Film dozwolony od lat...? „Film” 1972, nr 40, s. 7.

${ }^{8}$ Tamże.

${ }^{9}$ Tamże.

${ }^{10}$ Ten organ doradczy Centrali Wynajmu Filmów (a następnie Przedsiębiorstwa Dystrybucji Filmów), rekomendujący zakupy zagranicznych filmów do polskich kin, działał od 1958 r. do momentu wprowadzenia stanu wojennego.

${ }^{11}$ Regulamin Komisji do Spraw Kwalifikowania Filmów dla Dzieci i Młodzieży, w: Prawo Filmowe, dz. cyt., s. 98.

${ }^{12}$ H. Depta, Przed czym trzeba dziecko chronić, „Kino” 1999, nr 3, s. 10.

${ }^{13}$ Filmy były dozwolone od lat 7, 11, 14, 16 i 18. Co interesujące, taki podział sugeruje, że obecność w kinie dzieci, np. sześcioletnich, była niezgodna $\mathrm{z}$ prawem.
${ }^{14}$ A. Lewicki, Analiza ... dz. cyt., s. 121.

${ }^{15}$ K. Kucharski, Kino Plus. Film i dystrybucja kinowa w Polsce 1990-2000, Oficyna Wydawnicza Kucharski, Toruń, 2002; K. Kucharski, S. Salamon, Kino Plus 2. Film i dystrybucja kinowa w Polsce 2001-2003, Oficyna Wydawnicza Kucharski, Toruń 2005.

${ }^{16}$ A. Wróblewska, Rynek filmowy w Polsce, Wydawnictwo Wojciech Marzec, Warszawa 2014.

${ }^{17} \mathrm{http}$ //lumiere.obs.coe.int/web/search/ (dostęp: 1.07.2019).

${ }^{18}$ Niemniej należy zauważyć, że bardzo często dane te nie są zbieżne. Dla przykładu Kucharski podaje, że Girl Guide (reż. Juliusz Machulski, 1996) obejrzało 312622 osób, natomiast w bazie Lumiere odnajdziemy informacje o 308980 osobach. Z kolei Kosmiczny mecz (reż. Joe Pytka, 1996) według książki Kucharskiego obejrzało w Polsce 1415587 osób, a w bazie Lumiere jest mowa o 1433045 osobach. Takich różnic jest więcej, nie wspominając o wielu filmach z początku z lat 90., o których nie ma żadnych informacji ani w książce Kucharskiego, ani we wspomnianej bazie (jest bowiem tworzona od 1996 roku). W tym sensie jest trudna do ustalenia na przykład liczba widzów najpopularniejszego, jak się zwykło uważać, filmu polskiego w 1990 roku, czyli Porno (reż. Marek Koterski, 1989).

${ }^{19}$ Maty Rocznik Filmowy 1982, s. 50.

${ }^{20}$ Zestawienie informacyjne wyników rozpowszechniania filmów produkcji polskiej z roku 1982, w: Zestawienia informacyjne wyników rozpowszechniania w latach 1973-1986, Archiwum Akt Nowych (dalej: AAN), zesp. Naczelny Zarząd Kinematografii (dalej: NZK), sygn. 5/68, k. 24.

${ }^{21}$ W przypadku roku 1984 zastosowano zaokrąglenie do najbliższej wartości. Na przykład wedtug dokumentu Zestawienie informacyjne wyników rozpowszechniania filmów produkcji polskiej z roku 1984 obie części Akademii Pana Kleksa (reż. Krzysztof Gradowski, 1983) obejrzało 10836543 widzów, a według magazynu - 10837000 widzów.

${ }^{22}$ Na przykład jugosłowiański film Piękne jest życie (Život je lep, reż. Boro Drašković, 1985) nie ma kategorii wiekowej. Zob. W kinach i na kasetach, „Film” 1988, nr 26, s. 23.

${ }^{23}$ „,Czterej pancerni”” $i$,,Luna” pod presja, , ¿̇̇ycie Warszawy" 1968, nr 9 (7532), z 10 stycznia 1968 r., s. 6. Dziękuję za tę wskazówkę bibliograficzną Krzysztofowi Jajko.

${ }^{24}$ Zob. Regulamin ... dz. cyt., s. 98.

${ }^{25}$ Najlepsze filmy od premiery do roku bieżacego, AAN, zesp. Komitet Kinematografii, sygn. $2 / 247$. 


\section{EMIL SOWIŃSKI}

${ }^{26}$ Interesująca jest także różnica dotycząca widowni kinowej obu części Znachora. Z tabulogramu wynika, że widownia w 1988 r. jest liczniejsza, niż odnotowują dane zbiorcze (od początku dystrybucji) dwa lata później.

${ }^{27}$ Zob. Raport o stanie kin w Polsce 1984, AAN, zesp. NZK, sygn. 2/229, k. 14.

${ }^{28} \mathrm{~W}$ ironiczny sposób finał filmu zdradza Wanda Mirowska (filmoznawca, a także pracownik Miejskiego Zarządu Kin w Łodzi) w notacjach realizowanych przez Muzeum Kinematografii w ramach projektu ,Rozmowy o HollyŁodzi”: Sanitariuszka zostaje postrzelona i pada, ale w ostatniej chwili zdażyła wyjać legitymację partyjna i pokazać, że składki ma zapłacone do końca roku. Wtedy umiera spokojnie, szczéśliwa, że spetniła swój obowiązek wobec kraju. Zob. Notacja z Wandą Mirowska, http://www.hollylodz.kinomuzeum.pl (dostęp: 1.07.2019).

${ }^{29}$ Skrajnym przykładem na potwierdzenie tej tezy jest rok 1984. Wśród dwudziestu filmów o najwyższej frekwencji po roku wyświetlania było jedenaście filmów amerykańskich (cztery dozwolone od lat osiemnastu) i dziewięć polskich (trzy dla dorosłych). W sumie frekwencja na amerykańskich filmach wyniosła 29754422 widzów, a na polskich 27250 846. Dla porównania, każdy z dwudziestu filmów o najniższej frekwencji pochodził z krajów komunistycznych, a najmniej popularnym obrazem okazała się po raz kolejny produkcja z Korei Północnej (Szumia lasy), która zgromadziła na ośmiu seansach zaledwie... 96 widzów (średnio dwunastu na seans). Podaję za: „Mały Rocznik Filmowy" 1985, s. 72-76.

${ }^{30}$ Wszystkie dane przywołuję na podstawie „Małego Rocznika Filmowego” z 1984 r. oraz „Filmowych Serwisów Prasowych" z 1983 roku.

${ }^{31}$ Mimo że film wzbudzał kontrowersje (zob. Protest polskiego MSZ w związk z wyświetleniem francuskiego filmu ,,Shoah”, „Film” 1985, nr 21, s. 2.), to zdecydowano się na jego pokaz w Polsce. Jak wyjaśniał rzecznik rządu Jerzy Urban, decyzja o zakupie nie oznaczała jednak zmiany stanowiska władz wobec zawartych w nim treści (Krótko, „Film” 1985, nr 40, s. 2). Produkcja trafiła więc do kin, a fragmenty dotyczące Polski pokazano w telewizji.

${ }^{32}$ Zob. Stenogram z posiedzenia Komisji Kolaudacyjnej Filmów Fabularnych odbytej w dniu 27 stycznia 1984 roku, Archiwum Filmoteki Narodowej-Instytutu Audiowizualnego (dalej: AFINA), sygn. A-344, poz. 355.

${ }^{33}$ Po przyjęciu przez Pana Ministra mojego filmu „Nadzór" rozmawiałem na temat jego rozpowszechniania z dyrektorem Goszczurnym. Zos- tałem przez dyrektora poinformowany, że film ten znajdzie się $w$ normalnym, szerokim rozpowszechnianiu. Zob. List Wiestawa Saniewskiego z dnia 12 lipca 1984 roku do Jerzego Bajdora, AFINA, sygn. S-31373, k. 318.

${ }^{34}$ Pismo Departamentu Programowego NZK do Przedsiębiorstwa Dystrybucji Filmów z dnia 10 lipca 1984 roku podpisane przez Stanisława Goszczurnego, AFINA, sygn. S-31373, k. 317.

${ }^{35}$ Podaję za: „Mały Rocznik Filmowy” 1985, s. 72-76.

${ }^{36}$ K. J. Zarębski, dz. cyt., s. 9.

${ }^{37}$ Wątek ten pojawiał się również w wywiadach będących efektem badań widowni filmów dla dzieci przeprowadzonych przez moich studentów na zaliczenie konwersatorium „Film dla dzieci” (kurs prowadzony na Filmoznawstwie UŁ). I tak na przykład w jednym z wywiadów odnotowano oszustwo polegające na schowaniu młodszego brata pod kurtką, a w innym na zastosowaniu tak mocnego makijażu, aby bileter nie miał złudzeń, że ma do czynienia $\mathrm{z}$ osobą pełnoletnią. Motyw ten pojawia się również w reportażach telewizyjnych dotyczących kina w PRL (https://www.tvn24.pl/czarno-na-bialym, 42, m/kino-w-czasachprl,912181.html), a nawet programach publicystycznych (zob. Drugie śniadanie mistrzów z 20 lipca 2019 r.).

${ }^{38}$ M. Adamczak, Obok ekranu. Perspektywa badań produkcyjnych a spoleczne istnienie filmu, Wydawnictwo Uniwersytetu Adama Mickiewicza w Poznaniu, Poznań 2014, s. 131.

${ }^{39}$ Sprawozdanie Okręgowego Przedsiębiorstwa Rozpowszechniania Filmów w Koszalinie dotyczace skarg wraz z wykazem statystycznym GUS za okres od 1.01 do 31.12.1984 roku, w: Skargi i wnioski załatwione w 1984 roku. Zestawienia zbiorcze; sprawozdania; analizy jednostek podlegtych, AAN, zesp. NZK, sygn. 2/242, k. 30.

${ }^{40}$ Zob. Sprawozdanie OPRF $w$ Lodzi z przyjmowania, rozpatrywania $i$ załatwiania skarg $i$ wniosków w 1984 roku wraz z arkuszem statystycznym za okres od 1 stycznia do 31 grudnia 1984 r., w: Skargi $i$ wnioski załatwione w 1984 roku... dz. cyt., k. 51-52.

${ }^{41}$ Sprawozdanie Okręgowego Przedsiębiorstwa Rozpowszechniania Filmów w Koszalinie... dz. cyt., k. 31.

${ }^{42}$ Sprawozdanie OPRF w Opolu wraz z arkuszem statystycznym dot. skarg $i$ wniosków z 1984 roku, w: Skargi i wnioski załatwione w 1984 roku... dz. cyt., k. 61.

${ }^{43}$ W ogólnej ilości skarg-wniosków jakie wptynęty przeważaja skargi niezasadne a dotyczace między innymi: (...) domagania się wpuszczania 


\section{KLASYFIKACJA WIEKOWA FILMÓW...}

dzieci na filmy dla nich niedozwolone/granica wieku/. Jest to stosunkowo duża ilość skarg, wpisów dokonanych przez rodziców, którzy uważaja, ̇̇e odpowiadaja za wychowanie dziecka - czytamy w jednym ze sprawozdań z 1985 r. Zob. Wykaz statystyczny wptywu i sposobu załatwiania skarg $i$ wniosków OPRF Warszawa, w: Załatwianie skarg $i$ wniosków przez jednostki podległe Naczelnemu Zarzadowi. Sprawozdania roczna za 1985 r., AAN, zesp. NZK, sygn. 2/243, k. 108.

${ }^{44}$ Zob. Sprawozdanie z zakresu przyjmowania, rozpatrywania i załatwiania skarg $i$ wniosków w OPRF - Kraków w 1985 roku, w: tamże, k. 84 .

${ }^{45}$ Co ciekawe, ten typ skarg odnosi się nie tylko do młodzieży, ale również dorosłych. W sprawozdaniu OPRF w Gdańsku czytamy, w jaki sposób radzono sobie $\mathrm{z}$ tym problemem: W związku z powyższym [niewłaściwym zachowaniem się widzów podczas projekcji filmowej] poproszono Milicję Obywatelska o pomoc $i$ wspótpracę. Zob. Sprawozdanie z przyjmowania, rozpatrywania $i$ załatwiania skarg oraz wniosków w 1984 roku, w: Skargi i wnioski załatwione w 1984 roku... dz. cyt., k. 10.

${ }^{46}$ Igraszki, ,Film” 1988, nr 22, s. 23.

${ }^{47}$ L. Bukowiecki, Syzyfowa praca, ,Film” 1988, nr 46, s. 2.

${ }^{48} \mathrm{Na}$ inną przyczynę wpuszczania młodocianych na filmy dla nich niedozwolone pod koniec lat 80. wskazywał widz z Sopotu: Powszechnie nie jest respektowane przestrzeganie wieku widzów. Na filmy dla dorostych sa z reguty wpuszczani małoletni. Personel kin złożony calkowicie z kobiet jest zastraszany: nie wpuszczenie na widownię mtodocianego kończy się w najlepszym wypadku karczemna awantura i stekiem wyzwisk. Bileterki boją się wzywać milicję, by nie narazić się na zemstę rozwydrzonych chuliganów. Zob. Atmosfera, „Film” 1989, nr 8, s. 2.

${ }^{49}$ Wejście smoka, „Film” 1983, nr 6, s. 23.

${ }^{50}$ P. Strzelecki, Dynamiczne pięści mistrzów kung-fu, ,Odgłosy” 1982, nr 21, s. 9.

${ }^{51}$ Dokładna liczba to 11362210 widzów. Podaję za „Mały Rocznik Filmowy” 1983, s. 62.

${ }^{52}$ Najlepsze filmy... dz. cyt.

${ }^{53}$ R. Sas, W sprawie Smoka, ,Dziennik Łódzki” 1982, nr 137, s. 3.

${ }^{54}$ W 1978 r. film Wejście smoka był pokazywany w ramach przeglądu „Kinematograf Narodów” organizowanego przez Filmotekę Narodową. Legenda głosi, że szturmujący kino widzowie wybili szyby w drzwiach.

${ }^{55}$ Bilet na film mógł kosztować od 80 do $120 \mathrm{z}$, a u konika niekiedy nawet około $400 \mathrm{zł}$. Jak zauważa Grzegorz Fortuna jr., za te pieniądze można byto wówczas kupić miesięczny zapas chleba dla całej rodziny, 40 litrów mleka lub 36 paczek „Popularnych”. Zob. G. Fortuna jr, King Bruce Lee karate mistrz. Recepcja filmów sztuk walki w PRL-u, w: Poszukiwacze zaginionych znaczeń. Perspektywa (wy)twórcy, odbiorcy $i$ krytyka $w$ badaniach nad kultura audiowizualna, red. K. Łuczyńska, M. Stańczyk, Wydawnictwo Uniwersytetu Jagiellońskiego, Kraków 2016, s. 72.

${ }^{56}$ Brytyjczycy posunęli się nawet o krok dalej i wycięli ujęcia, w których widoczne były kopnięcia w krocze i szyję oraz sekwencję, w której rozbite butelki są używane jako broń. Ponadto wycięli fragmenty (również z materiałów promocyjnych), w których pojawiało się nunchaku. Zob. https://bbfc.co.uk/case-studies/enter-dragon (dostęp: 10.07.2019).

${ }^{57}$ H. Depta, Film ... dz. cyt., s. 7.

${ }^{58}$ Wejście smoka, dz. cyt., s. 23.

${ }^{59}$ Krótko, ,Film” 1983, nr 33, s. 2.

${ }^{60}$ Krótko, ,Film” 1985, nr 32, s. 2.

${ }^{61}$ Krótko, „,Film” 1982, nr 29, s. 2.

${ }^{62}$ Krótko, „Film” 1982, nr 38, s. 2.

${ }^{63}$ Wejście smoka, „Film” 1982, nr 38, s. 15.

${ }^{64} \mathrm{Z}$ perspektywy współczesnego badacza jest to dziś zagadnienie problematyczne, albowiem większość stron prezentujących mistrza karate w takich czasopismach, jak „Film” „Ekran”, „Kino”, czy „Razem”, które są dostępne są w bibliotekach (przynajmniej łódzkich) jest wybrakowana. Może to sugerować, że zostały one powyrywane przez fanów aktora.

${ }^{65}$ Z przykrościa muszę stwierdzić, że ogarną Was szat na tle Bruce'a Lee. Wybaczcie, ale jak dtugo można to znosić? We wszystkich środkach masowego przekazu-Bruce Lee. Znositam to spokojnie myślac, że to nowa moda, która szybko minie, ale niestety to jest szat, który opanowat nawet poważnych, dojrzatych ludzi. Ja tymczasem interesuję się Alainem Delonem i jego twórczościa, życiem prywatnym, filmami. Wiem, że on nie umie, ,walić" jak ten Lee, ale to chyba nie powód by o nim zapominać. Zob. Mniej o Bruce Lee, „Film” 1982, nr 36, s. 15. Autorka listu doczekała się odpowiedzi od fanki aktora: Radzę Ci pójść na ten film jeszcze raz. Przyjrzyj się walce. Przecież to jest sztuka nie do osiagnięcia dla przeciętnego człowieka, a nie żadne ,walenie”, które raczej kojarzy się z bijatyka uliczna. Czy zauważyłaś, żeby Bruce znęcat się nad jakimś czlowiekiem? Mial zawsze szacunek do ludzi (...). Napisałaś, że Delon nie umie „walić”. Mylisz się, umie i to w catym tego stowa znaczeniu. Jeśli oglądałaś film ,, Glina” z Delo- 


\section{EMIL SOWIŃSKI}

nem, to powinnaś wiedzieć, co mam na myśli (...). Bruce Lee, „Film” 1983, nr 2, s. 15.

${ }^{66} \mathrm{~W}$ notowaniu 60 . listy przebojów Franek Kimono zajął nawet piąte miejsce, przegrywając tylko z takimi zespołami, jak: Maanam (Kocham cie, kochanie moje), Classix Nouveaux (Never again), Lady Punk (Mniej niż zero) i Republika (Znak ,, =’). Zob. http://www.lp3.pl/alpt.phtml?m=1\&nn=57 (dostęp: 10.07.2019).

${ }^{67}$ Zob. E. Królikowska, Drzazgi. O filmie Wojciecha Wójcika, „Film” 1982, nr 27, s. 12-13.

${ }^{68}$ „Mały Rocznik Filmowy” 1984, s. 76.

${ }^{69}$ Nie mogłem oprzeć się pokusie, żeby podzielić się refleksjami na temat filmu ,, Karate po polsku”. Co miat w ogóle znaczyć tytut? Czy ktoś, kto go wymyślit miał na celu ukazanie prawdziwego karate, czy tylko ściagnięcie ludzi do kin (chodzi tu o szat po filmie ,, Wejście Smoka")? (...) Rozdrażniła mnie scena, w której bohater pokonuje trzech przeciwników. Uderzyt ich najwyżej dwa razy, a w rezultacie wszyscy byli tak zmasakrowani, jakby przeszedt po nich huragan. Może więc to była komedia? Jeżeli tak-zwracam honor (...) - pisał zdegustowany czytelnik „Filmu”. Zob. Karate po polsku, „Film” 1983, nr 41, s. 23.

${ }^{70} \mathrm{Na}$ marginesie warto zauważyć, że plakat filmu prezentował zdjęcie aktora Edwarda Żentary, który był ubrany w kimono.

${ }^{71}$ G. Fortuna jr, Wprowadzenie: Szok transformacji, „Panoptikum” 2016, nr 15 (22), s. 9.

72 N. Sławińska, Niż psychiczny, „Film” 1985, nr 21, s. 9.

${ }^{73}$ H. Depta, Niż psychiczny, ,,Film” 1985, nr 27, s. 23.

${ }^{74}$ Wszystkie wspomniane w tej części tekstu plakaty można odnaleźć w cyfrowych bazach Filmoteki Narodowej - Instytutu Audiowizualnego (http://www.gapla.fn.org.pl) oraz Biblioteki Uniwersytetu Łódzkiego (http://www.bcul.lib.uni.lodz.pl).

${ }^{75}$ Zaświadcza o tym wspomnienie nastoletniego wówczas Piotra Zwierzchowskiego: $W$ połowie lat 80. trzynastoletni chłopak, wracajacy ze szkoty, przechodzit obok dużej witryny, $w$ której reklamowano najnowszy repertuar filmowy. Dopiero zaczynat interesować się kinem, ale już pilnie śledził wszystkie nowości, które miaty pojawić się na ekranach. Szczególnie często wywieszano plakaty i fotosy zapowiadajace filmy polskie, przynajmniej taki obraz zachowat się $w$ mojej pamięci. Z pewnościa przyglądałem się wszystkim fotosom, zapamiętałem niektóre. Wśród nich znalazty się na przyktad ,, Thais” Ryszarda Bera, ,Magiczne ognie” Janusza Kidawy i ,Ognisty aniol" Macieja Wojtyszki. Nic o nich nie wie- działem, ale nagość aktorek przyciagnęła moja uwagę. Pamiętam, jak z żalem myślałem o tym, że nie wpuszcza mnie do kina z powodu mojego wieku. Oglądajac te filmy po latach, dziwiłem się, jak mało istotne, oprócz ,,Thais”, byty $w$ nich sceny nagości. Niemniej jednak to właśnie te zdjęcia przyciagnęty moja uwage. Zob. P. Zwierzchowski, Nagość jako strategia promocyjna kina polskiego lat 80., „Images. The International Journal of European Film, Performing Arts and Audiovisual Communication" 2018, t. 23, nr 32, s. 174.

${ }^{76}$ „Mały Rocznik Filmowy” 1986, s. 78.

${ }^{77}$ K. Jachymek, Świadectwa wizualne w badaniach nad historia kina polskiego $w$ perspektywie zachodzacych przemian obyczajowych, w: Źródła wizualne w badaniach nad historia polskiego kina, red. P. Zwierzchowski, Wydawnictwo Uniwersytetu Kazimierza Wielkiego, Bydgoszcz 2018, s. 114-115.

${ }^{78}$ Badacz wskazuje na plakaty takich filmów, jak: Łuk Erosa (reż. Jerzy Domaradzki, 1988), Porno, Wilczyca (reż. Marek Piestrak, 1983), Widziadło (reż. Marek Nowicki, 1984), Alabama oraz Co lubia tygrysy (reż. Krzysztof Nowak, 1989).

${ }^{79}$ Klasycznym przykładem tej - dodajmy, że z powodzeniem stosowanej również dziś przez dystrybutorów - strategii jest oczywiście thumaczenie tytułu filmu Dirty Dancing na Wirujacy seks.

${ }^{80} \mathrm{Na}$ jeszcze innej wersji plakatu zamieszczono hasło reklamowe: jazz i erotyzm.

${ }^{81}$ H. Depta, Film... dz. cyt., s. 7.

${ }^{82}$ List Henryka Depty z dnia 23 lutego 1983 roku, w: Skargi, zażalenia, interwencja, sprawozdania, korespondencja, AAN, zesp. NZK, sygn. 2/239, k. 92.

${ }^{83}$ Choć skąpo ubrane gwiazdy filmowe (i nie tylko) odnajdziemy niemal w każdym z numerów „Filmu” z lat 80. (najczęściej w dziale „Kinorama"), to nagość na okładce pojawia się dopiero w 1988 roku. Bohaterką pierwszej strony tygodnika była wtedy Maria Probosz (kadr z filmu Łabędzi śpiew Roberta Glińskiego). Zob. „Film” 1988, nr 26, s. 1.

${ }^{84}$ Piotr Zwierzchowski zauważa nawet, że „Ekran” o wiele częściej niż „Film” wykorzystywał jako ilustrację zdjęcia prezentujące nagie kobiety. Zob. P. Zwierzchowski, Czasopisma filmowe jako źródta $w$ badaniach nad kinem PRL-u-aspekt wizualny, w: Źródta wizualne, dz. cyt., s. 56.

${ }^{85}$ K. Jachymek, dz. cyt., s. 112-113.

${ }^{86}$ Oto fragment jednego $\mathrm{z}$ takich listów: Zwracam się z uprzejma prośba o zwrócenie uwagi na poziom filmów wyświetlanych $w$ kinach doz- 


\section{KLASYFIKACJA WIEKOWA FILMÓW...}

wolonych dla dzieci i młodzieży. Filmy te często zawieraja sceny erotyczne, sceny nagości, nie mówiąc już o ich poziomie moralnym. Przypominam, że do dziś mamy światly wzór $w$ kinematografii radzieckiej, gdzie nigdy nie spotka się takich scen, obowiąuje skromność stroju, a nigdy też nie brakuje wyraźnych ocen moralnych $i$ wartościujacych ludzkie zachowania (...). Zob. List do Gtównego Urzędu Kontroli Publikacji Prasy $i$ Widowisk z dnia 21 lutego 1984 roku, AAN, zesp. Główny Urząd Kontroli Publikacji Prasy i Widowisk (dalej: GUKPPiW), sygn. 184, k. 42.

${ }^{87}$ Odpowiedź na pismo dotyczace filmu , Grease” produkcji USA, AAN, zesp. GUKPPiW, sygn. $187, \mathrm{k} .12$. W podobny sposób o pojęciu pornografii wypowiadał się także dyrektor Okręgowego Urzędu Kontroli Prasy Publikacji i Widowisk na łamach „Filmu”. Zob. Starać się działać mądrze. Rozmowa z Przemysławem Marciszem, „Film” 1983, nr 45, s. 18.

${ }^{88} \mathrm{~W}$ poprzednich dekadach obecna w filmach erotyka nie była już tak łagodnie oceniana przez decydentów, o czym świadczą problemy, jakie spotkały film Seksolatki (reż. Zygmunt Hübner, 1971). Zob. A. Misiak, Kinematograf kontrolowany, Cenzura filmowa w kraju socjalistycznym i demokratycznym (PRL $i$ USA). Analiza socjologiczna, Universitas, Kraków 2006, s. 286-287.

${ }^{89}$ Cyt. za: A. Lewicki, Seks i Dziesiąta Muza. Erotyzm, relacje intymne $i$ wzorce genderowe $w$ kinie przedkodeksowym (1894-1934), Wydawnictwo Uniwersytetu Wrocławskiego, Wrocław 2011, s. 497-498.

${ }^{90} \mathrm{Już}$ od dluższego czasu nosiłem się z zamiarem skomentowania poczynań telewizji, dowolnie „opracowujacej” emitowane filmy; miarke przebrała świąteczna projekcja filmu Stevena Spielberga ,Szczęki”. Jakiś uzbrojony w nożyczki rekin pogryzt i zniszczył całkowicie cała sekwencje poczatkowa (nawiasem mówiac, jedyna naprawdę budzaca groze w calym filmie), a także nie omieszkat wyciać stynnej sceny z nieboszczykiem wyplywajacym z dziurawej todzi, dzięki czemu przestrach oceanografa Hoopera byt w tym momencie całkowicie niejasny dla widza, który wcześniej nie widziat filmu w kinie. ,Szczęki” nie sa romantyczna komedia, tylko dreszczowcem, więc usuwanie podobnych scen uważam za nonsens. Nie wydaje mi się równiez, aby widok nagiej dziewczyny, fotografowanej notabene z dużej odległości spod wody, byt w stanie zbulwersować telewidzów. Film emitowano po pótnocy, co sugerowato, ze byt przeznaczony dla widzów dorostych - po co więc ta ostrożność? I tak bezustannie raczeni jesteśmy $w$ kinach i telewizji wszelkiego rodzaju golizna, najczesściej w filmach rodzimej produkcji. Zob. T. Beksiński, Taśmożerne rekiny, „Film” 1988, nr 11, s. 23. Głos ten spotkał się również z aprobatą innych widzów: Uważam, że nad ta sprawa nie wolno przejść do porzadku dziennego, należy się nią zająć poważnie (...). Parę lat temu wyświetlono ,Złoto MacKeny” w całości, łacznie ze scena kapieli, ale przed ostatnia zeszłoroczna emisja usunięto ja - widocznie, żeby nie gorszyć co wrażliwszych telewidzów. Wniosek z tego, iz dopiero od niedawna grasuje $w$ telewizji uzbrojony $w$ nożyczki, spóźniony wielbiciel kodeksu Haysa. Zob. Taśmożerne rekiny, „Film” 1988, nr 19, s. 23. Co ciekawe, również dziś takie zabiegi zdarzają się o wiele częściej w telewizji aniżeli w kinie. Zob. M. Kurdupski, Polsat znów pokazat ocenzurowana wersje ,Wilka z Wall Street”, https://www.wirtualnemedia.pl/artykul/polsatznow-pokazal-ocenzurowana-wersje-wilka-zwall-street (dostęp: 15.07.2019).

${ }^{91}$ Dozwolone od lat piętnastu były także obfitujące w sceny erotyczne filmy Ewy i Czesława Petelskich, które są - jak pisał Krzysztof Kornacki - dobrym przykładem dokonujacej się erozji ideologicznej poprzez erotyzm rodzimej X muzy. Cyt. za: K. Kornacki, Naga władza. Polskie kino erotyczne (schyłkowego PRL-u), „Studia Filmoznawcze” 2008, nr 29, s. 213. ${ }^{92}$ List z dnia 9 stycznia 1984 roku mieszkanki Limanowej ws. filmu „Magiczne ognie”, w: Skarga dotyczaca filmu ,Magiczne ognie”, AAN, zesp. NZK, k. 2.

${ }^{93} \mathrm{Na}$ inną przyczynę wskazywał Janusz Kidawa: Byta petnia stanu wojennego. Krajem rzadziła Wrona czyli grupa nikomu blizej nieznanych panów w mundurach. Dyrektor Marcisz z racji prostego żotnierskiego umystu i rangi oficerskiej zostat w kinematografii łacznikiem Wrony $i$ to on wywolat alarm $w$ resorcie, gdzie odpowiadat za obrone cywilna. Alarm - jakby grozit nam atak nuklearny, byt spowodowany telefonem w sprawie fotosów gołej panienki wiszacej w gablotach kin wyświetlajacych „Magiczne Ognie” (...). Panienka która dostapiła zaszczytu zainteresowania się nią najwyższego organu PRL stanu wojennego była półamatorka uzdolniona aktorsko (...). Nazywała się Krystyna Puchała. Traf chciat że jeden z pułkowników Wrony też się nazywat Puchała i byt jej rodzonym ojcem. Ale skad mogłem to przewidzieć w czasie kręcenia?. Zob. J. Kidawa, Janusza Kidawy dokumentacja. Część czwarta. Film fabularny, 2003, s. 295, publikacja w zbiorach Biblioteki Państwowej Wyższej Szkoły Fil- 


\section{EMIL SOWIŃSKI}

mowej Telewizyjnej i Teatralnej w Łodzi, sygn. 46946. (zachowałem oryginalną pisownię). Dziękuję za tę wskazówkę bibliograficzną Jarosławowi Grzechowiakowi.

${ }^{94}$ Zob. Sprawozdanie Okręgowego Przedsiębiorstwa Rozpowszechniania Filmów w Koszalinie... dz. cyt., k. 31.

${ }^{95}$ Janusz Kidawa wskazywał, że największą popularnością cieszyły się pokazy pierwszej wersji: Mam informacje, że w niektórych kinach reklamowano: Ostatni seans przed wycięciem cenzury, a thum walit drzwiami i oknami kupując bilety u , koników", po wyjątkowo paskarskich cenach. Ci, którzy biletu nie dostali, roznosili wiadomość o szalejącej w kraju cenzurze generałów. Zob. List Janusza Kidawy $z$ dnia 24 kwietnia 1984 roku, w: Skarga dotyczaca filmu... dz. cyt., k. 6.

${ }^{96}$ „Mały Rocznik Filmowy” 1984, s. 75.

${ }^{97}$ Taką samą kategorię wiekową przyznano filmowi w 1968 r., gdy po raz pierwszy pojawił się w polskich kinach.

${ }_{98}^{98}$ Betty, ,Film” 1988, nr 5, s. 23.
${ }^{99}$ Francuska aktorka w momencie premiery filmu była jedną z najczęściej pojawiających się gwiazd na łamach „Filmu”. Zresztą magazyn ten czynił podobnie, gdy na początku lat 80 . na polskich ekranach pojawiła się Tess (reż. Roman Polański, 1979). Wtedy to niekwestionowaną gwiazdą tygodnika była Nasstasja Kinski, która na zdjęciu w jednym z numerów pojawiła się nago z wężem owiniętym wokół ciała. Zob. Przeciwko Tess, „Film” 1983, nr 1, s. 8.

100 „Mały Rocznik Filmowy” 1988, s. 70.

${ }^{101}$ Warto w kontekście Betty przywołać wspomnienie jednego z użytkowników portalu filmweb.pl: Ten tragiczny film po raz pierwszy... widziatem $w$ kinie, wiele lat temu, $w$ matym miasteczku zrobili nocny seans dla dorostych o 24:00, ze to niby erotyczny czy coś $w$ tym stylu uzasadniali, kolejki po bilety byly spore. Film puścili tylko $1 \mathrm{raz}$... Zob. https://www.filmweb.p1/film/Betty-1986-35078/discussion (zachowałem pisownię oryginalną) (dostęp: 15.07.2019). 